\title{
Świat, \\ który przezwyciężamy \\ i pozostawiamy za soba \\ Import, rozpowszechnianie i widownia filmów z krajów kapitalistycznych w Polsce Ludowej w latach 1949-1956 w świetle badań archiwalnych
}

\section{KONRAD KLEJSA}

Intuicyjne przypuszczenie, że $\mathrm{w}$ okresie stalinowskim w repertuarze polskich kin dominowały filmy z krajów „demokracji ludowej”, jest oczywiście słuszne i nie wymaga, jak sądzę, obszerniejszych wyjaśnień. Potrzebne są już one jednak przy opisie skali tej dominacji (w szczególności przez odniesienie do tytułów spoza bloku wschodniego) oraz analizie konkretnych mechanizmów ją wytwarzających. Inaczej mówiąc, należałoby odpowiedzieć na pytanie, w jaki sposób system rozpowszechniania filmów w stalinowskiej Polsce łączył założenia polityczne z aspektami ekonomicznymi i praktyką organizacyjną. Tak sformułowany cel niesie ze sobą wiele pytań szczegółowych, dotyczących oferty repertuarowej (mianowicie: do jakiego stopnia wśród filmów kierowanych do dystrybucji uwzględniano produkcje z krajów zachodnich?), a po części także - widowni (tj. czy władze instytucji odpowiedzialnych w pierwszym dziesięcioleciu Polski Ludowej zarówno za produkcję, jak i rozpowszechnianie filmów - a zatem działającego do końca $1951 \mathrm{r}$. „Filmu Polskiego" ", następnie przemianowanego na Centralny Urząd Kinematografii - monitorowały preferencje i reakcje widza?).

Zagadnienia te - w odniesieniu do okresu stalinowskiego - były jak dotąd przedmiotem niewielu badań (podobnie zresztą jak szerzej pojęta kultura filmowa tego czasu ${ }^{2}$ ). Podejmując je, historyk kultury filmowej może wziąc pod uwagę różne typy źróder: 1) niepublikowane dokumenty z zasobów archiwalnych, centralnych i lokalnych, 2) materiały promocyjne: plakaty i programy, 3) czasopiśmiennictwo z danego okresu, ze szczególnym uwzględnieniem prasy filmowej, 4) dane z prasy lokalnej, szczególnie cenne z uwagi na repertuary kinowe ${ }^{3}$. Oczywiście najlepsze wyniki daje połączenie różnych źródeł, niemniej w niniejszym artykule ograniczę się do analizy dokumentów przechowywanych w Archiwum Akt Nowych, głównie w teczkach serii „Generalna Dyrekcja Filmu Polskiego” oraz „Centralny Urząd Kinematografii” z zespołu „Ministerstwo Kultury i Sztuki” ". Ponadto przywołam dokumenty wytworzone przez Podkomisję ds. Filmu przy Wydziale Kultury Komitetu Centralnego PZPR, przy czym skromna objętość tego zasobu pozwala wyrazić przypuszczenie, że dokumentacja prac Podkomisji rozproszona zresztą pomiędzy różnymi jednostkami archiwalnymi ${ }^{5}$ - bądź została 
zachowana jedynie częściowo, bądź nie była sporządzana z przesadną skrupulatnością. Komunikacja między sektorem kinematografii a władzami partyjnymi miała bowiem również charakter nieformalny i odbywała się także ustnie. W odniesieniu do okresu stalinowskiego jest to tym bardziej prawdopodobne, że GDFP oraz CUK kierował wówczas - na stanowisku, odpowiednio, generalnego dyrektora oraz prezesa - Stanisław Albrecht ${ }^{6}$, brat Jerzego Albrechta, członka Komitetu Centralnego Polskiej Partii Robotniczej (1945-1948), a następnie PZPR (1949-1968).

Szczegółowa analiza obecności konkretnych filmów na polskich ekranach wymagałaby przygotowania kompletnych repertuarów z poszczególnych kin ${ }^{7}$. Czasochłonna próba ich zebrania (w odniesieniu do pierwszej dekady po II wojnie światowej) jest obecnie podejmowana i być może przyniesie zniuansowanie sądów prezentowanych w niniejszym artykule. Ten bowiem koncentruje się na procesach top-down, tj. realizowanej przez warszawską „centralę” polityce repertuarowej. Dlatego kryterium wyjściowym analizy może być liczba (pełnometrażowych) filmów z poszczególnych krajów skierowanych do rozpowszechniania w kolejnych latach. Dysponując takimi danymi (zob. tabela $1^{8}$ ), w odniesieniu do pierwszej dekady po wojnie można się pokusić o wyróżnienie dwóch okresów polityki repertuarowej (1945-1948 oraz 1949-1956), zaś w ich obrębie - czterech segmentów o węższym zakresie czasowym.

W pierwszym z nich - od zakończenia wojny (a na terenach opanowanych przez Armię Czerwoną i władzę PKWN - od 1944 r.) do mniej więcej jesieni 1946 r. - niemal wszystkie filmy zachodnie, które pojawiały się w repertuarach kinowych, były nakręcone przed $1940 \mathrm{r}$. Innymi słowy, posługiwano się (zapewne bezprawnie, bowiem producenci raczej nie otrzymywali dochodów z wynajmu prowadzonego przez nowego polskiego dystrybutora) kopiami, które były w Polsce w obiegu przed wojną i przetrwały okupację. Znaczną część repertuaru stanowiły oczywiście filmy sowieckie (także nowe, tj. nakręcone podczas wojny), jak również przedwojenne filmy polskie, cieszące się - jak wynika z raportów okręgowych przedstawicielstw Ministerstwa Informacji i Propagandy ${ }^{9}$ - największą popularnością.

Drugi podokres rozpoczynałby się od jesieni 1946 r. (gdy w dystrybucji pojawiły się pierwsze legalnie zakupione filmy zagraniczne) i trwał do połowy roku 1949. W tym okresie w kinach wyświetlano sporo filmów z krajów kapitalistycznych, w tym wiele produkcji hollywoodzkich (w maju 1949 r. łączna liczba tytułów z państw zachodnich była tylko nieznacznie mniejsza od łącznej liczby filmów z krajów bloku sowieckiego) ${ }^{10}$, a wśród nowych tytułów wprowadzonych do dystrybucji przeważały - do końca 1948 r. - filmy z państw kapitalistycznych. Od połowy 1949 r. stopniowo wycofywano je z ekranów, co było konsekwencją zmiany w polityce programowej (zarówno gdy idzie o produkcję filmową, jak i decyzje repertuarowe) po Zjeździe Filmowym w Wiśle, który w polu kultury filmowej stał się formalnym potwierdzeniem ,zwrotu stalinizacyjnego" "11. W latach 1950-1954 repertuar kinowy w Polsce był budowany już głównie z filmów pochodzących z krajów demokracji ludowej.

W 1954 r. na łamach prasy kulturalnej pojawiło się kilka artykułów mówiących o niezadowoleniu widowni z oferty filmowej. W marcu w „Przeglądzie Kulturalnym” ukazała się notka, w której Jerzy Płażewski stwierdził wprost, że pod koniec 


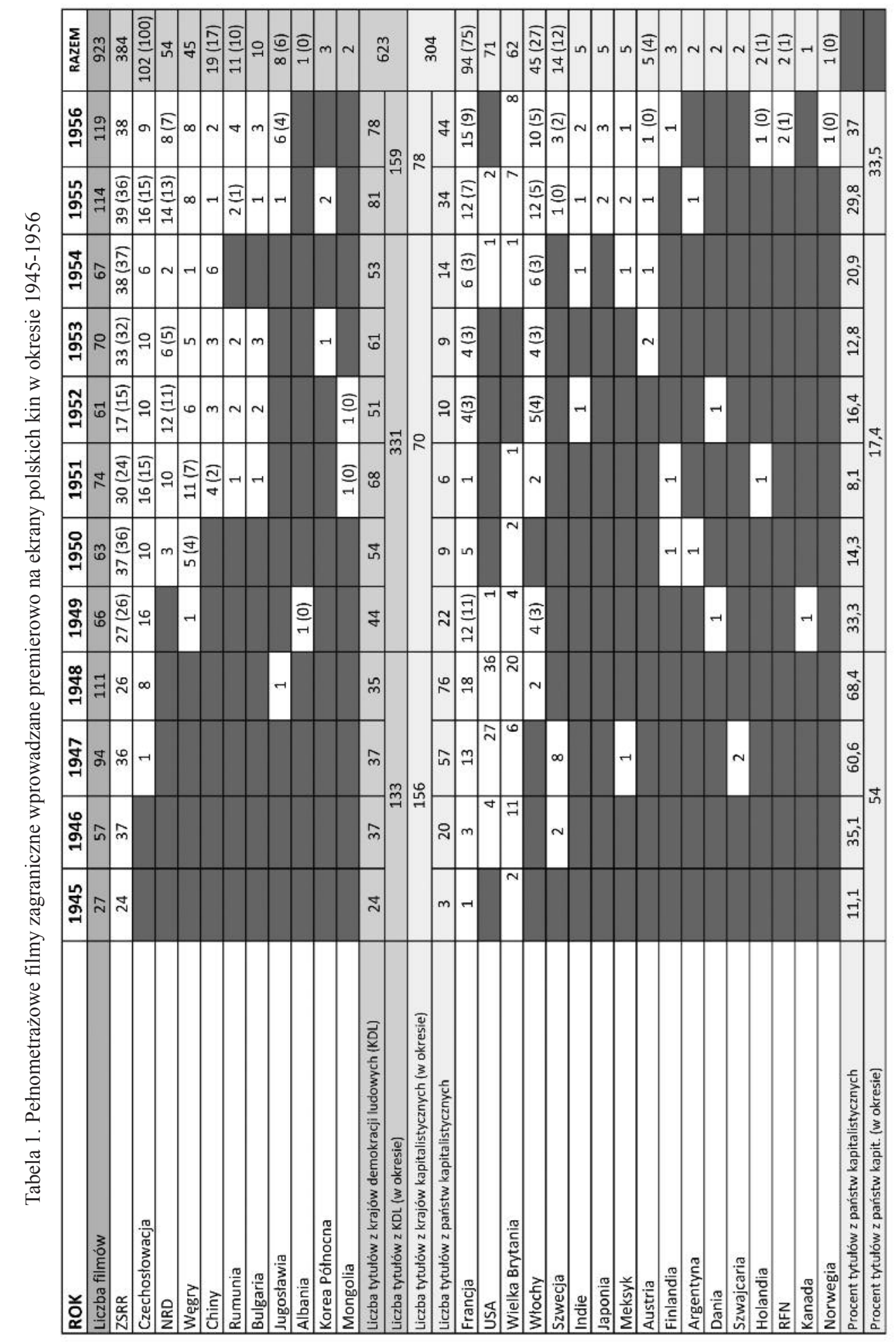


ubiegłego roku dostownie nie było na co pójść do kina ${ }^{12}$. W jednym z kolejnych numerów opublikował zaś obszerniejszy artykuł, w którym po części usprawiedliwiał Centralę Wynajmu Filmów (pula filmów wybitnych wyczerpała się, na Zachodzie zwiększyt się nacisk kapitalistycznej cenzury na postępowych twórców), ale w zakończeniu konkludował: niezadowolenie z repertuaru naszych kin, uderzająca zgodność $w$ postulatach $i$ coraz silniejsze przeświadczenie, że widz jest aktywnym współgospodarzem naszej kinematografii - oto, co rzuca się w oczy przy czytaniu listów naszych korespondentów ${ }^{13}$. Trudno stwierdzić, czy krytyka ta miała wpływ na zmianę polityki w zakresie importu filmów - uwagi o słabości repertuaru pojawiały się także w protokołach CUK, ale bez odniesień do krytycznych publikacji prasowych. Tak czy inaczej, w 1955 i 1956 r. - a zatem jeszcze na długo przed Październikiem - na ekrany trafiła nieco większa liczba filmów z krajów zachodnich.

\section{Zasady kwalifikowania}

Ponieważ Film Polski, a następnie CUK były ściśle podporządkowane władzom partyjno-państwowym, stosunek obu instytucji wobec filmów zachodnich był odzwierciedleniem bieżącej polityki - nie tylko zagranicznej (zaostrzenie rywalizacji zimnowojennej od końca 1947 r.), ale także wewnętrznej. W polu kultury oddziaływanie tej polityki dotyczyło relacji między warunkami produkcji (w krajach socjalistycznych i kapitalistycznych) a jakoby generowaną przez nie ideologią wytwarzanego tekstu. Julian Hochfeld - marksistowski socjolog, podówczas jeden z orędowników „socjalistycznego humanizmu”, de facto oznaczającego zgodę na „postępową" dominację sowiecką oraz socrealizm - wykładał ten pogląd w następujący sposób: działając na drodze kulturalnego rozwoju, mamy nie tylko prawo, ale $i$ obowiąek odrzucać z pogarda (...) czapkowanie przed każdym, nawet podgniwajacym importem kulturowym z krajów kapitalistycznych (...). Korzystajmy z szacunkiem ze wszystkiego, co w kulturze świata byto i jest prawdziwie postępowe: korzystajmy z dorobku socjalistycznej kultury Związu Radzieckiego (...); dzisiejsza literatura kapitalistycznego Zachodu chce dowieść, że czlowiek jest istota antyspołeczna, a zarazem słaba, mizerna, jeśli zaś silna - to koniecznie drapieżnie silną; że rzadza człowiekiem poza nim samym umiejscowione, irracjonalne namiętności, często najprymitywniejszy seksualizm; $i$ że ludziom obce sa i rozum, $i$ wola, $i$ szlachetność, i dążenie do lepszego. Taki jest-zgódźmy się-świat kapitalistyczny ${ }^{14}$.

Polityka programowa Filmu Polskiego, a potem CUK względem filmów zagranicznych była realizowana na wielu polach i obejmowała kolejne etapy rozpowszechniania. Pierwszym z nich była sama decyzja dotycząca zakupu (lub nie) danego filmu, podejmowana przez komisję, której skład i zasady działania kilkukrotnie się zmieniały. Od połowy 1946 r. (przynajmniej przez rok, lecz nie dłużej niż przez dwa lata) miała ona, jak można sądzić na podstawie wspomnień Leona Bukowieckiego ${ }^{15}$, status nieformalnego ,ciała eksperckiego”, złożonego z krytyków związanych z czasopismem „Film”, a zarządzanego przez Jerzego Bossaka ${ }^{16}$. Pierwszy ślad powołania bardziej sformalizowanego organu przypada na marzec 1948 r., kiedy to powołano komisję kwalifikującą filmy do zakupu w składzie: delegat Biura Programowego Naczelnej Dyrekcji, delegat Biura Programowego przy CZKiEF [Centralny Zarząd Kin i Eksploatacji Filmów] oraz delegat Biura Zakupu 
i Sprzedaży Filmów ${ }^{17}$. W zarządzeniu nie sprecyzowano kryteriów oceny, co stało się w sierpniu 1949 r. (a zatem trzy miesiące przed Zjazdem Filmowym w Wiśle), gdy utworzono - jako ciało doradcze Centrali Wynajmu Filmów - Komisję Kwalifikacyjną dla Ocen Filmów Importowanych i Eksportowanych (miał nią kierować dyrektor Biura Zagranicznego Obrotu Filmów), która przy ocenie filmu winna zanalizować wartość ideologiczno-artystyczna oraz przydatność spoleczna filmu ${ }^{18}$. Kilka miesięcy później, w lutym 1950 r., ponownej modyfikacji uległa zarówno nazwa Komisji (teraz nazywała się Komisją Ocen Filmów do Zakupu i Sprzedaży), jej skład, jak i kryteria, wedle których miała oceniać filmy (zniknęło ,artystyczne” kryterium oceny, dołączono zaś znaczenie propagandowe ${ }^{19}$ ). Wszystkim „mutacjom" de facto tej samej Komisji szefowała - mniej więcej do połowy 1950 r. - ta sama osoba: Rita Radkiewiczowa ${ }^{20}$ (żona Stanisława Radkiewicza ${ }^{21}$, ówczesnego - od grudnia 1944 do końca 1954 r. - Ministra Bezpieczeństwa Publicznego ${ }^{22}$ ). W czerwcu 1951 r. nastąpiła ostatnia korekta - gremium nosiło (do 1957 r.) nazwę Komisja Ocen Filmów. Kryteria jej działania nie uległy modyfikacji, natomiast sprecyzowano, że w skład komisji wchodzą: dyrektor Centrali Wynajmu Filmów, przedstawiciele Wydziałów Kultury Centralnej Rady Związków Zawodowych oraz Związku Samopomocy Chłopskiej, a także 5 literatów i publicystów, których powotuje imiennie Generalny Dyrektor ${ }^{23}$. Ponadto przewodniczacy powinien zawiadamiać o posiedzeniach Komisji przedstawicieli właściwych Wydziałów KC PZPR. O kolejnych zmianach w zasadach działania Komisji archiwa milczą. Pewien trop pojawia się natomiast w artykule opublikowanym w „Przeglądzie Kulturalnym" na początku 1955 r., w którym czytamy o szerokiej komisji oceniajacej zakupowane filmy (w której skład wchodza również po raz pierwszy przedstawiciele krytyki filmowej) ${ }^{24}$.

O działalności Komisji w pierwszej połowie lat 50. wiemy niewiele; inaczej niż w przypadku późniejszej (powołanej w 1957 r.) Filmowej Rady Repertuarowej, nie zachowała się dokumentacja prac tego gremium. Jedynym świadectwem są, ponownie, relacje Bukowieckiego. Na ich podstawie można zrekonstruować liczbę członków Komisji (krytyk wspomina o 9 osobach, choć najpewniej chodzi mu o obecnych na konkretnym zebraniu ${ }^{25}$ ) oraz jej skład. Otóż - poza reprezentantem Filmu Polskiego lub CUK oraz samym Bukowieckim - w jej pracach brali udział: Bohdan Czeszko, Andrzej Miłosz (brat Czesława), Roman Szydłowski (krytyk teatralny) ${ }^{26}$, a sporadycznie także Julian Tuwim, Jarosław Iwaszkiewicz i Jerzy Putrament ${ }^{27}$. Ponadto w głosowaniach uczestniczyli urzędnicy, np. niewymieniony z nazwiska szef kadr pewnej instytucji artystycznej (jeden z największych durni, jakiego znałem $w$ moim życiu) ${ }^{28}$. O konkretnych tytułach odrzuconych przez Komisję pisze Bukowiecki mało, najwięcej miejsca poświęcając filmom z Niemiec wschodnich.

Pomimo braku dokumentacji prac samej Komisji o wytycznych dotyczących filmów zagranicznych wiemy całkiem dużo. Wynika z nich niezbicie, że „,rola polityczna", będąca podstawowym kryterium oceny, była ściśle związana z krajem pochodzenia filmu - zgodnie z założeniem, że z krajów demokracji ludowej nie mogą pochodzić filmy „nieprawomyślne”, dominujące w kinematografiach opartych na kapitalistycznym systemie produkcji. Założenie to jest czytelne w prasie filmowej z okresu stalinowskiego - w recenzjach oraz sprawozdaniach z festiwali zagranicznych. Przykładowo, w 1951 r. na łamach „Filmu” swoimi wrażeniami z Cannes dzielił się sam dyrektor Albrecht: Doszło do konfrontacji dwóch rodzajów 


\section{KONRAD KLEJSA}

twórczości filmowej. Sztuce schyłkowego kapitalizmu, dekadenckiej, formalistycznej, a nierzadko wręcz wrogiej człowiekowi, przeciwstawiła się sztuka życiowej prawdy i humanizmu, sztuka walczaca o pokój i szczęście ludzkości. Té ostatnia reprezentowała w pierwszym rzędzie kinematografia radziecka i państw demokracji ludowej ${ }^{29}$.

Jak zatem uzasadniano fakt, że filmy z krajów kapitalistycznych od czasu do czasu pojawiały się jednak na polskich ekranach? Jeszcze w grudniu 1949 r. Biuro Polityczne Komitetu Centralnego PZPR konstatowało: Kina nasze nie moga otrzymać ze Zwiazku Radzieckiego i Krajów Demokracji Ludowej niezbędnej ilości filmów dla wypetnienia programu i spetnienia roli politycznej, stawianej polskiej kinematografii. Filmy krajów kapitalistycznych niosa ze soba w przeważnej mierze obca $i$ wroga propagandę $i$ winny być z tych względów $w$ zasadzie z naszych ekranów rugowane. Ten stan rzeczy pogłębia konieczność rozwoju polskiej produkcji filmowej ${ }^{30}$. Warto zwrócić uwagę, że potrzeba finansowania produkcji rodzimej była uzasadniana niedoborem filmów z krajów demokracji ludowej.

Odnoszące się do filmów z krajów kapitalistycznych określenia w pierwszym rzędzie, w przeważnej mierze oraz $w$ zasadzie sygnalizują możliwość zaistnienia wyjątków. Będzie o nich mowa podczas zebrania aktywu GDFP w styczniu 1950 r., którego protokół jest jednym z cenniejszych materiałów unaoczniających polityczne uwikłania systemu rozpowszechniania w latach stalinowskich. Włodzimierz Sokorski - główny politruk „odcinka kulturalnego”, a zarazem wiceminister kultury i sztuki (a w latach 1952-1956 - minister) - w charakterystycznej nowomowie zapewniał: Jedyne kryterium, które powinniśmy stosować, jest to, czy dany film, który wystartowat może nie pod bezpośrednim naciskiem polityki imperializmu $i$ urodzit się $w$ szczelinach pseudo-postepowych, nie zawiera ładunku wrogiego, który zahamowałby nam proces kształtowania świadomości człowieka. Powinniśmy pokazywać filmy, które oddają nam rzeczywisty fragment imperialistycznego życia, ale które nie maja w założeniu kształtowanie wrogiego dla nas człowieka, po prostu oddaja fragmenty moralno-obyczajowe niezafatszowanego życia. Takich filmów prawie nie ma, czasem jednak pokazują się w wytwórniach francuskich i częściej włoskich. Takie filmy powinny iść przy rozumnej krytyce. Rozumiem ja nie jako wrzask, który podnosi prasa, że po co nam filmy, w których żona zdradza męża, bo u nas tego nie ma. Krytyka powinna pokazywać braki życia $i$ wiazać je rozumowo z procesem, który jest $u$ nas ${ }^{31}$.

Passus ten jest symptomatyczny o tyle, że w latach stalinowskich, a w gruncie rzeczy przez cały okres istnienia Polski Ludowej, kinematografie francuska i włoska będą traktowane w sposób poniekąd ulgowy, jako wprawdzie kapitalistyczne, ale zarazem „,na drodze postępu” (abstrahuję tu od rangi artystycznej poszczególnych filmów oraz wiedzy o lewicowych inklinacjach konkretnych twórców). Przeświadczenie takie znalazło odzwierciedlenie w decyzjach dotyczących importu, o czym świadczą dane liczbowe (zob. Tabela 1): w ogólnej puli 148 tytułów z krajów kapitalistycznych, skierowanych do dystrybucji w Polsce w okresie 1949-1956, ponad połowę stanowiły filmy nakręcone we Włoszech lub Francji (lub koprodukowane przez te kraje).

W przywołanym protokole mówi się o filmach włoskich wprost: spełnity cel, zobrazowaty nędzę życia $w$ krajach kapitalistycznych i należałoby je faworyzo$w a c^{32}$. Akcentując ten zamysł, Sokorski utyskiwał: U nas jest pod tym względem 
pewna sztampa: filmy radzieckie naświetla się z punktu widzenia ideologicznego, jeżeli chodzi o film zachodnioeuropejski, naświetla się go od strony artystycznej, pięknych aktorek. To trzeba przełamać. (...) Istota krytyki filmowej jest rzecza bardzo ważna i jest zagadnieniem chwycenia tego przez Wojewódzkie Komitety Partyjne. Dobra krytyka filmowa pozwoli nam chwilowo rozszerzyć zakres, jeżeli chodzi o możliwości puszczenia filmów zachodnioeuropejskich. Czasem moglibyśmy puścić taki film, który w sposób ostry demaskuje filozofię tamtego okresu (w klubach robotniczych itd.), gdybyśmy to potrafili właściwie naświetlić w dyskusji bezpośrednio po takim filmie. Oczywiście jednak podstawowym założeniem, jeżeli chodzi o filmy zagraniczne, będzie zdobywanie wielkiego nurtu, jaki przedstawia Związek Radziecki, a film kapitalistyczny będzie raczej ilustracja tego świata, który przezwyciężamy i pozostawiamy za soba ${ }^{33}$. Warto zauważyć, że Sokorski kieruje zalecenie wprost do organów wojewódzkich, sugerując w ten sposób najpewniej nacisk na lokalną prasę (w niej przecież także ukazywały się recenzje filmów).

W podobnym tonie wypowiedział się Jerzy Bossak, który podejmując temat filmów zagranicznych, zwrócił uwagę na hamletyzujący stosunek przedsiębiorstwa do tego zagadnienia. Stosunek jest niezdecydowany: wyświetla się je i chciatoby, aby jak najmniej ludzi je ogladało. Jest tu niekonsekwencja. Wydaje mi się, że gdybyśmy dopuszczając do wyświetlania filmów zagranicznych potrafili sprecyzować, jaki kapitat polityczny można osiagnać na podstawie wyświetlania danego filmu, możnaby dużo osiagnać. (...) Pozostawiamy zbyt wiele samodzielności w złym tego słowa znaczeniu, dziennikarzom filmowym, bo nie dajemy im do rak materiatów. Jeżeli film zagraniczny dopuszczamy do wyświetlania, to mamy pewne argumenty typu politycznego i należy je udostępnić, jeżeli chcemy kapitat polityczny z tego filmu wyciagnać. (...) Przy ocenie filmu odgrywa rolę moment fiskalny, który powinien być wykluczony ${ }^{34}$. Innymi słowy, Bossak postulował kontekstualizację filmów przez sterowaną krytykę filmową, zaś w zakończeniu swej wypowiedzi sugerował, by kwestie ekonomiczne (moment fiskalny) - choć nie jest jasne, czy chodzi o koszty zakupu licencji, czy przychody z eksploatacji - nie przysłaniały aspektów ideologicznych.

Jak już zostało powiedziane, decyzje o skierowaniu konkretnych tytułów do rozpowszechniania były monitorowane przez Wydział Kultury PZPR. Wydaje się, że nadzór ten nie był ciągły, tj. istniał raczej jako możliwość, z której partia korzystała sporadycznie, w momentach ,ideologicznego wzmożenia”. W dokumentacji zachowało się tylko jedno świadectwo takich działań - mianowicie, w połowie września 1950 r. dyrektor Radkiewiczowa przesłała do dyrektora Albrechta notatkę służbową: wykaz filmów z krajów kapitalistycznych wyświetlanych $w$ ostatnich miesiacach oraz planowanych do wyświetlenia w najbliższym czasie. Albrecht przekierował korespondencję do Wydziału Kultury KC PZPR z odręcznym dopiskiem: Wniosek na Sekretariat co do likwidacji filmów anglosaskich na naszych ekranach ${ }^{35}$. Towarzysz Lesław Wojtyga (wówczas zastępca dyrektora Wydziału Kultury, a wkrótce wiceprezes CUK) odpowiedział pismem, w którym wyraził zgodę na wyświetlanie filmów wyprodukowanych $w$ krajach bloku kapitalistycznego jedynie w wypadku uznania ich oddziaływania za społecznie uzyteczne ${ }^{36}$. Natomiast dwa tygodnie później Radkiewiczowa przesłała kolejną notatkę, z podaniem krótkiej treści i uzasadnieniem możliwości wyświetlania, przekierowaną do $\mathrm{KC}$ jako skorygowany program rozpowszechniania filmów zachodnich ${ }^{37}$. 
Jest to fascynujący dokument - właśnie z uwagi na uzasadnienia możliwości wyświetlania. Można powiedzieć, że w grę wchodziły dwa główne kryteria: dramaturgiczne oraz pozatekstualne, zwłaszcza odnoszące się do postawy politycznej twórców. W niektórych przypadkach sięgano po oba, jak choćby w odniesieniu do filmu Siódmy krzyż (The Seventh Cross, reż. Fred Zinnemann, 1944), który rozważano jako planowany do rozpowszechniania (nie wszedł ostatecznie do dystrybucji). Scharakteryzowano go w następujący sposób: Film wyprodukowany w pierwszych latach wojny za czasów Roosevelta wg. powieści Anny Seghers. Akcja rozgrywa się w Niemczech hitlerowskich w roku 1936. Z obozu koncentracyjnego ucieka 7 więźniów. Film przedstawia dzieje poszczególnych uciekinierów, związanych z ruchem oporu, kierowanym przez klase robotnicza. Zawiera silne akcenty antyhitlerowskie, nie zaś antyniemieckie. Dlatego też powinien być na naszych ekranach ze względu na swa treść i postać autorki. Odtwórca głównej roli Spencer Tracy nie byt zamieszany $w$ żadna akcję antykomunistyczna $w$ Hollywood ${ }^{38}$. Uzasadnienia związane z konkretnymi twórcami dominują w części dotyczącej filmów francuskich, w której zostali wskazani reżyserzy (René Clement, Jacques Becker) oraz aktorzy (Gerard Philippe, Noël-Noël) należacy do postępowych pracowników kinematografii, a ponadto twórcy, którzy podpisali tzw. apel sztokholmski ${ }^{39}$ (Simone Renault, Maurice Chevalier, Jean-Paul Le Chanois) czy wprost członkowie Francuskiej Partii Komunistycznej (Louis Daquin, Vladimir Posner). W uzasadnieniu dotyczącym filmu Hrabia Monte Christo sięgnięto do argumentu prawdopodobnie najsilniejszego: film grany jest $w$ Związu Radzieckim ${ }^{40}$.

Najczęściej jednak ocenie poddawano samą fabułę. W uzasadnieniu wyświetlania brytyjskiego filmu Renegat (Fame is the Spur, reż. Roy Boulting, 1947) czytamy: Jest to historia zdrady, jaka popetnia jeden z przywódców Partii Pracy wobec klasy robotniczej ${ }^{41}$. Z kolei o filmie Scott na Antarktydzie (Scott of the Antarctic, reż. Charles Frend, 1948) napisano: bogata i wplywowa część spoleczeństwa angielskiego nie zgadza się na finansowanie wyprawy, nie przewidujac żadnych korzyści materialnych. Nie ma także w filmie tendencji dyskontowania tej wyprawy na rachunek Anglii. Z tego też powodu film może być wyświetlany ${ }^{42}$. A gdyby ta argumentacja mogła zostać oceniona jako niewystarczająca, w piśmie Radkiewiczowej pojawia się dopisek: posiadamy jedynie 3 kopie ${ }^{43}$, co jest dowodem na to, że ich liczba, redukowana w odniesieniu do filmów zachodnich, była postrzegana jako istotny instrument polityki repertuarowej. Identycznie brzmiąca adnotacja widnieje zresztą przy tytułach dwóch innych anglojęzycznych filmów familijnych: Powrót Lassie oraz Czerwony rumak (jego fabułę streszczono jako przyjaźn człowieka, konia i psa ${ }^{44}$ ). Co ciekawe, z opisów dowiadujemy się, że z obu filmów usunięto wszelkie niepożądane akcenty społeczno-polityczne ${ }^{45}$. Szczegóły tych ingerencji nie są znane; informacji na ten temat nie udało się (na razie) odnaleźć także w aktach Głównego Urzędu Kontroli Prasy, Publikacji i Widowisk.

\section{Geografia importu}

Informacje na temat szczegółowych zasad importu filmów w okresie stalinowskim są rozproszone po wielu jednostkach archiwalnych, spośród których kapitalne znaczenie ma teczka Narada ekonomiczna pracowników kinematografii, a dokładniej - zawarty w niej referat Konstantego Gordona, realizatora filmów dokumen- 
talnych, który w CUK odpowiadał za „odcinek” współpracy z zagranicą. Dzięki niemu wiemy, że import z krajów kapitalistycznych nie odbywał się - jak w przypadku wymiany z krajami bloku sowieckiego ${ }^{46}$ - na zasadzie państwowych uzgodnień dwustronnych, lecz uwzględniał oddzielne umowy w odniesieniu do każdego filmu bądź grupy filmów reprezentowanych przez tego samego zagranicznego dystrybutora. Były one zazwyczaj - z wyjątkiem filmów brytyjskich - kupowane na zasadach fix ${ }^{47}$ (umowa na konkretną kwotę), nie zaś procentowych.

Pod względem formalno-prawnym sprowadzanie filmów z krajów zachodnich odbywało się częściowo na zasadach podobnych jak przed wojną, tj. przedstawiciel handlowy strony polskiej (Filmu Polskiego bądź CUK) kupował od zagranicznego dysponenta praw licencję na określony czas uprawniającą do pokazów. Zazwyczaj to delegat strony polskiej za granicą podpisywał umowę wstępną (najczęściej zadanie to wypełniał Jan Korngold ${ }^{48}$ ), choć niekiedy to zagraniczni dystrybutorzy wysyłali swoich przedstawicieli nad Wisłę (w protokole z marca 1950 r. czytamy, że Anglicy starają się przyjechać do Polski ${ }^{49}$ ). Następnie zagraniczny dystrybutor przesyłał do Polski kopię filmu, na sprzedaż którego liczył, ta zaś była przedmiotem oceny dokonywanej przez Komisję (a następnie przez cenzurę). Ponadto urzędnicy Filmu Polskiego i CUK byli zależni od Ministerstwa Handlu Zagranicznego, które dysponowało dewizami.

Odrębne zasady obowiązywały w odniesieniu do filmów amerykańskich - do maja 1950 r. obowiązywała umowa z kwietnia roku 1947, którą z Motion Pictures Export Association (spółką zajmującą się eksportem filmów amerykańskich do krajów zza żelaznej kurtyny ${ }^{50}$ ) podpisał Jerzy Toeplitz - ówczesny dyrektor Wydziału Zagranicznego w Filmie Polskim ${ }^{51}$. W myśl jej postanowień strona polska mogła dystrybuować 65 filmów z listy 100 tytułów opracowanej przez stronę amerykańską (nie zachowała się w dokumentacji przechowywanej w AAN). Umowa ta nie została „skonsumowana” w całości: początkowa fala filmów made in Hollywood, która na kilka miesięcy zalała polskie ekrany (od połowy 1947 do końca 1948 r. - zob. Tabela 1), została powstrzymana w 1949 r., gdy na ekrany trafił jeden film amerykański (zaś rok później nie pojawił się żaden). Oczywiście filmy hollywoodzkie odnosiły sukcesy frekwencyjne i okazały się nadzwyczaj rentowne. Ponieważ jednak były „nie po linii” nowej polityki wobec filmów zagranicznych, stały się dla władz polskiej kinematografii przysłowiowym ,gorącym kartoflem”. W marcu 1950 r. narzekano: Około 13 filmów jest niewybranych. Sprawa jest niezałatwiona, ogladamy i odrzucamy filmy, nie ma decyzji, co wziać ${ }^{52}$. Ostatecznie także w 1951, 1952 oraz 1953 r. do dystrybucji nie trafił żaden film produkcji amerykańskiej. W kolejnych dwóch latach CUK zakupił jeszcze tylko trzy filmy z USA. Pierwszym z nich był nakręcony na podstawie powieści Jacka Londona w 1942 r. Dziennik marynarza (The Adventures of Martin Eden, reż. Sidney Salkow), który trafił do dystrybucji w 1954 r. (bohater czuje się obco w wyższych sferach społeczeństwa kapitalistycznego - czytamy w programie filmu ${ }^{53}$ ). Zaś dwa kolejne tytuły, wprowadzone na ekrany w 1955 r., zostały wyprodukowane poza systemem dużych wytwórni: traktowany dziś jako prekursorski wobec Nowej Fali film Maty uciekinier (The Little Fugitive, reż. Ruth Orkin, Ray Ashley, Morris Engel, 1953) oraz Sól ziemi (The Salt of the Earth, reż. Herbert J. Biberman, 1954), którego reżyser, scenarzysta (Michael Wilson) oraz producent (Paul Jarrico) znaleźli się na „czarnej liście Hollywood” 54. 


\section{KONRAD KLEJSA}

Co ciekawe, na początku dekady w kontekście filmów amerykańskich doszło do istotnej różnicy zdań między Albrechtem a Radkiewiczową; dyskusja unaocznia apodyktyczny styl zarządzania właściwy Generalnemu Dyrektorowi:

ALBRECHT: Ile nowych tytułów wprowadzamy co miesiąc? Osiem. Gros filmów można na podstawie streszczeń odrzucić. Radzieckie filmy sa prawie niewątpliwe, zostaje więc 5-6 filmów miesięcznie, do czego wystarczy jeden człowiek. (...) Twierdze, że przez komisje powinny być ogladane tyko filmy watpliwe. Na filmy amerykańskie jest jeden na tysiąc znośny do wypuszczenia, na angielskie - dwa na tysiac. (...)

RADKIEWICZOWA: Jeżeli chcemy mieć komisję na poziomie, to powinna ona ogladać wszystkie filmy.

ALBRECHT: Nie widzę więcej niż 7 filmów do oglądania.

RADKIEWICZOWA: Ogladaliśmy filmy amerykańskie, z których jeden byt bardzo straszny. Oglądała go cenzura i jest dyskusja, czy właśnie nie pokazywać tych strasznych. Można postawić tak sprawę, że chodza tylko filmy radzieckie i czeskie, ale to nie jest rozwiazanie zagadnienia.

ALBRECHT: Nie widzę powodu oglądania przez komisję więcej filmów niż 7 miesięcznie, resztę można ogladać bez Komisji Ocen.

RADKIEWICZOWA: A więc wracamy do starej dyskusji, aby ogladać bez Komisji Ocen. Uważam jednak, ze Komisja Ocen jest od tego, aby kwalifikować filmy do zakupu. Mówię o filmach, które się do nas sprowadza.

ALBRECHT: Twierdze nawet, że przez urzędników nie ma większej potrzeby oglądania filmów. Dziura $w$ niebie się nie stanie, jeżeli nie pokażemy nawet dobrego filmu amerykańskiego ${ }^{55}$.

Z przytoczonej rozmowy widać wyraźnie, że repertuar był dla Albrechta funkcją zależną od wytycznych ideologicznych, mierzoną współczynnikami ilościowymi, nie jakościowymi. W GDFP, a następnie w CUK realizowano bowiem założenia planu sześcioletniego (1950-1955), nadzorowanego przez Państwową Komisję Planowania Gospodarczego (każdy sektor gospodarki - nie wyłączając kinematografii - ustalał akceptowane przez PKPG plany gospodarcze, które były głównym dokumentem referencyjnym w dyskusjach z pierwszej połowy lat 50.). Myliłby się jednak ten, kto spodziewałby się, że w wytycznych wynikających z planu oraz raportach z jego wykonania akcentowano wynik finansowy - np. przychody ze sprzedaży biletów. Owszem, takie dane były odnotowywane w raportach poszczególnych Okręgowych Zarządów Kin, i to ze sporą szczegółowością (przykładowo w 1952 r. arkusz Sprawozdanie z wykonania ustug kin miejskich za dany miesiąc liczył 27 kolumn ${ }^{56}$ ), jednak ani w części opisowej tych sprawozdań, ani w stenogramach dyskusji kierownictwa Filmu Polskiego czy CUK kwestie przychodów, dochodów i zysków nie zajmowały wiele miejsca (jeśli w ogóle były podejmowane). Zachowało się natomiast nadzwyczaj wiele sprawozdań, w których główne kryteria ilościowe - a także towarzyszące im analizy zestawień tabelarycznych, często utrzymane w stalinowskiej nowomowie - dotyczyły parametrów geografii politycznej: relacji między tytułami wyprodukowanymi w bloku sowieckim i państwach kapitalistycznych.

Ten rodzaj sprawozdawczości pojawił się w 1949 r.; we wcześniejszych dokumentach dominują zestawienia nie „bloków geopolitycznych”, ale po prostu poszczególnych krajów. W dokumentacji GDFP oraz CUK wzmianki o nich pojawiają 
się głównie w stenogramach rozmów. Przykładowo w pochodzącym z końca 1951 r. protokole z posiedzenia kierownictwa kinematografii dyrektor Mieczysław Dytko z Centrali Wynajmu Filmów wygłasza taki oto „raport z wykonania planu”: Wegrzy - planowane 8 tytułów, wykonano 5. NRD - planowane 5 tytułów - otrzymaliśmy 9. Francja 3-3. Włochy-4, otrzymaliśmy 1 tytut. Inne kraje: planowane 4-otrzymaliśmy 2. Zwiazek Radziecki do roku 1950 dawat nam 35 tytułów, w roku 1950 - 45, zaś w roku 1951 otrzymaliśmy 32 tytuły, w tej ilości byto 10 filmów dokumentalnych i 3 programy składane. Jakie sa możliwości wykonania planu importu? Zwiazek Radziecki - należy się liczyć z brakiem 2-3 pozycji, NRD - plan jest już wykonany, a nawet przekroczony. Wegry-przewidujemy, że zabraknie nam 1-2 tytułów do wykonania planu. Chiny - plan wykonaliśmy, dodatkowo otrzymaliśmy dwa filmy rumuńskie i jeden film bułgarski. Wykonanie planu importu osiagnie cyfrę 90 tytułów, co da 95 procent wykonania planu rocznego. (...) Jeżeli chodzi o odrzucanie filmów, to sprawy te ida przede wszystkim w kierunku odrzucania pozycji z krajów zachodnich, ze Zwiazku Radzieckiego został odrzucony film ,, Sylwia”, z Czechosłowacji na 15 tytułów odrzucono 3, NRD - z 15 odrzucono 5, $z$ angielskich 5 odrzucono 5, francuskich 18 -odrzucono 12, wtoskich 6 -odrzucono 4 (...). Możemy stwierdzić, że ostatni rok uptynąt pod znakiem braku tytutów frekwentownych. Ostatnie wyprodukowane filmy czeskie sa niechętnie ogladane przez publiczność. W kwalifikacji natrafiamy na duże trudności, bo filmy produkowane przez kraje demokracji ludowej powtarzaja się w tematyce. (...) W dużym stopniu produkcję zachodnia zastapity filmy NRD i filmy chińskie ${ }^{57}$.

Jeśli przytoczony wyimek jest $\mathrm{w}$ jakimś stopniu nietypowy dla ówczesnej sprawozdawczości, to wyłącznie $\mathrm{z}$ uwagi na brak wskazania relacji procentowych (które w bardziej efektowny sposób pokazałyby, że np. z filmów czechosłowackich odrzucono tylko 20 proc., za to z angielskich - aż 100). W okresie „sześciolatki” były one głównym trybem urzędniczego opisu zagadnień dotyczących rozpowszechniania. Przykładowo pod koniec 1952 r. dyrektor CWF raportował: W roku bieżacym oceniliśmy 113 filmów, odrzuciliśmy 27, przyjęliśmy 86, odsiew stanowit 24 procent, przy czym z państw demokracji ludowej 23,5, a z państw zachodnich $53,5 \%$. Z przywołanych danych widać, że „odsiew” w odniesieniu do państw zachodnich był procentowo niemal dwukrotnie większy niż w odniesieniu do filmów „demoludowych"; pomimo tej okoliczności uznano za niezbędne wyjaśnić: odsiew w tym roku byt dlatego mniejszy, że filmy sprowadzamy ostrożniej ${ }^{58}$.

\section{Polityka repertuarowa}

Relacje między liczbą filmów z krajów demokracji ludowej a tych z państw kapitalistycznych były kwantyfikowane zarówno na poziomie centralnym, jak i w wymiarze lokalnym, dotyczącym konkretnych kin. W okólniku z maja 1951 r. podtrzymano obowiązek (nie udało się ustalić, kiedy dokładnie został on wprowadzony) takiego uktadu repertuaru kin w miastach o więcej niż dwóch kinach, aby przynajmniej na jednym z ekranów byt stale wyświetlany film radziecki. Natomiast zasadę, że filmy radzieckie winny być terminowane na ekranach na minimum 50\% dni, która stanowi raczej kryterium mechaniczne, należy stosować jako wytyczna orientacyjna. Obowiązującym jest dla ekspozytury limit widzów produkcji radzieckiej nadany przez Centralę $i$ wynikający z niego stosunek poszczególnych produkcji 


\section{KONRAD KLEJSA}

do ogólnej liczby widzów ${ }^{59}$. Słowo „limit” należy tu rozumieć jako „poziom” (a de facto jako minimalną akceptowalną liczbę), natomiast zwrot ,,poszczególne produkcje" odnosił się do grup filmów, w raportach statystycznych oznaczonych jako: produkcja polska, radziecka, „KDL” (ten często powtarzany akronim oznacza kraje demokracji ludowej) oraz ,inne”, przy czym w tej ostatniej kategorii kryły się zarówno filmy amerykańskie, jak i zachodnioeuropejskie.

Urzędnicy CWF zdawali sobie sprawę z mimowolnych konsekwencji przyjęcia systemu ,parytetów” dla poszczególnych kinematografii. Dyrektor Dytko ujawniał: na przestrzeni 1952 r. nie byliśmy nigdy w takiej sytuacji, abyśmy mogli wybierać wśród filmów radzieckich czy té filmów demokracji ludowej. Ilość kwalifikowanych filmów z tych krajów z trudem wystarczała na pokrycie naszego zapotrzebowania ilościowego, nie mówiąc już o możliwości selekcji tematycznej czy té selekcji z punktu widzenia wartości artystycznych. Nieliczne odrzucone filmy z krajów demokracji ludowej to pozycje nie nadajace się do rozpowszechniania ze względu na fatszywe ustawienie takich czy innych problemów, a nie ze względu na dublowanie takiej czy innej tematyki. Większa swobodę tematyki i formy mieliśmy w filmach produkcji zachodniej. Stąd też wytworzyła się paradoksalna sytuacja, że $z$ pośród filmów tych produkcji rzeczywiście dopuszczane byty w zasadzie tylko filmy o wysokiej formie artystycznej, ciekawej tematyce i na ogót bardzo atrakcyjne. Niewatpliwie powoduje to dezorientację części widzów, która mogłaby oceniać catość produkcji zachodniej na podstawie tych nielicznie dobranych filmów. Nasze braki $w$ dziedzinie filmów lekkich, któreby stawiaty istotne problemy $w$ niefrasobliwej, rozweselajacej, przyjemnej dla widza formie, w ostatnim roku jeszcze się pogłębity, a to na skutek szczególnie mocnego wyeksploatowania właśnie tego typu filmów ${ }^{60}$.

Przywołany passus jest interesujący z co najmniej dwóch powodów. Po pierwsze, braki w dziedzinie filmów lekkich były, jak widać, dolegliwością rozpoznaną przez władze CWF. Po drugie, można odnieść wrażenie, że szef instytucji odpowiedzialnej za rozpowszechnianie doradza, aby wprowadzać na ekrany większą liczbę „słabszych” filmów (zachodnich) - po to, by zapobiec „dezorientacji” widzów, skorych do utożsamiania filmów francuskich czy włoskich z wysoką jakością (zwróćmy uwagę, że podobnie makiaweliczny pomysł przywołała wcześniej Radkiewiczowa: jest dyskusja, czy właśnie nie pokazywać tych strasznych).

Pierwsze oznaki zmiany w sposobie myślenia o repertuarze - tj. ślad kiełkującego zamysłu, aby zwiększyć liczbę filmów z państw zachodnich - można odnaleźć w dokumentach CUK z połowy 1954 r. W sprawozdaniu za drugi kwartał 1954 r. odnotowano, że celem zwiększenia ilości tytułów filmów fabularnych zagranicznych dokonano ponownej weryfikacji poprzednio odrzuconych 7 filmów francuskich oraz 2 filmów włoskich ${ }^{61}$ (w tabelarycznym raporcie wykonania ,planu pracy” użyto innego określenia: zrehabilitowano siedem filmów francuskich $i$ dwa włoskie ${ }^{62}$ ). I choć w 1954 r. w obiegu było łącznie więcej tytułów pochodzących z krajów kapitalistycznych, to jednak zmniejszono - w stosunku do roku poprzedniego - liczbę kopii na tytuł ${ }^{63}$ (zob. Tabela 2 - warto pamiętać, że zawiera ona dane dotyczące nie tylko tytułów premierowych, ale wszystkich wyświetlanych w danym roku). Widoczna w liczbie tytułów przewaga filmów sowieckich staje się jeszcze wyraźniejsza, gdy weźmiemy pod uwagę liczbę kopii - w 1954 r. Centrala Wynajmu Filmów dysponowała ponad 9600 kopiami filmów sowieckich w porównaniu z około 


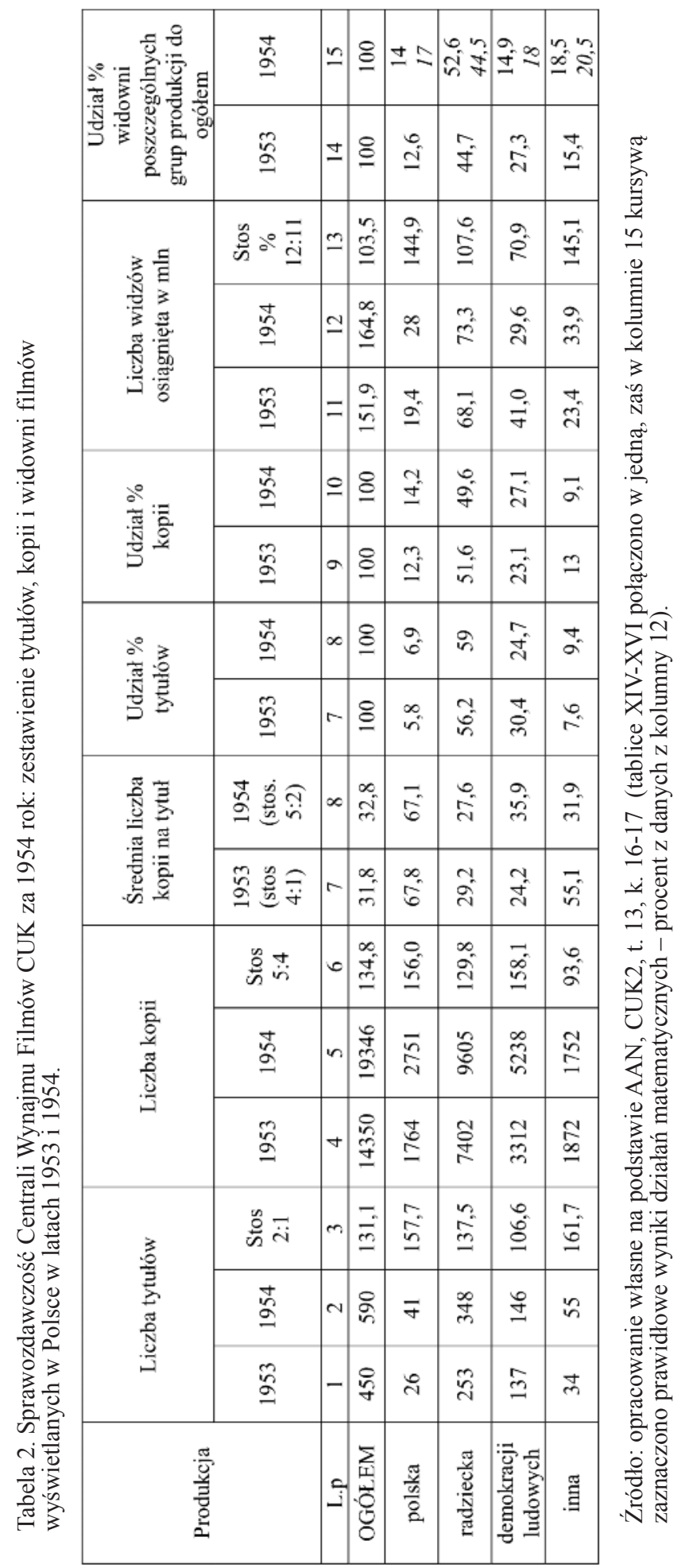




\section{KONRAD KLEJSA}

2750 kopiami filmów polskich i liczbą kopii filmów z krajów kapitalistycznych na poziomie 1750. Gdyby zaś zsumować wszystkie kopie filmów sowieckich, polskich oraz z innych krajów demokracji ludowej (co dałoby wynik 17 590), okazałoby się, że chodzi o dziesięciokrotną przewagę nad zasobem dzieł z państw kapitalistycznych.

Wydaje się, że poluzowanie polityki repertuarowej począwszy od drugiej połowy 1954 r. miało przyczyny ekonomiczne i mogło być spowodowane także oddolną presją. Charakterystyczny pod tym względem jest raport ekspozytury Centrali Wynajmu Filmów w Krakowie za rok 1955. Po spłaceniu ideologicznego trybutu w obszernej, liczącej kilka stron swoistej „,preambule”, kreślącej przemiany społeczne w Małopolsce od ,galicyjskiej nędzy”, przez międzywojenną działalność Komunistycznej Partii Polski, aż po budowę Nowej Huty, następuje właściwa część sprawozdania, zawierającego dość krytyczną ocenę oferty filmów sowieckich, a zarazem domagającego się większej liczby filmów zachodnich. Uważamy, że bardzo stuszna jest polityka Centrali Wynajmu Filmów, dająca nam w roku ubiegłym wiele i dobrych filmów produkcji krajów zachodnich. Uważamy, że te właśnie filmy winny być demaskatorskim narzędziem, odkrywajacym bolesna prawdę w krajach tak zwanego ,wolnego świata”. Filmy te maja poza tym jedna najpoważniejsza zalete dla naszego widza. Mówia językiem własnych krajów i prawdę życia pokazują środkami własnych narodów. Nie można im postawić zarzutu propagandy. Czy spetniła swa role demaskatorska , Ciemna rzeka”, którą w Krakowie ogladnęło 64 tysiace widzów? Niewatpliwie tak. Nie doszły nas stuchy, że jest to propaganda, ale komentarzy w rodzaju , straszne”, ,, ależ gnębiono tych ludzi”, ,, co to kobiety tam przeżywaja" styszeliśmy wśród widzów po wyjściu z kina dość sporo. Z tych względów wydaje się nam stusznym maksymalne wykorzystanie filmów w rodzaju „Ciemnej rzeki”, „, Ceny strachu”, ,, Uroku szatana”, „Pierwszy po bogu” i innych, które różnymi środkami artystycznymi wyrażają uczucia i pragnienia prostego człowieka żyjącego w krajach zachodnich. Zwiększony wachlarz zróżnicowanych treściowo $i$ artystycznie filmów $w$ roku ubiegtym (...) wzbogacit nam arsenat oddziaływania ${ }^{64}$. Uzasadnienie jest cokolwiek frapujące, poniekąd zbliżone do przywołanej już dyskusji o celowości pokazywania złych filmów amerykańskich; jednak w tym wypadku to nie niskie walory artystyczne, lecz właściwe ,profilowanie” tematyki społecznej było uzasadnieniem potrzeby importowania większej liczby tytułów zachodnich. A ponieważ sformułowania w rodzaju „to są świetne filmy” lub ,widownia domaga się takich produkcji” nie wchodziły w grę, pozostawało sięgnąć do argumentacji właściwej zideologizowanej nowomowie, w której doskonale mieściła się niezbędność posiadania ,,arsenału oddziaływania zwiększonym wachlarzem”. Nawiasem mówiąc, ten „militarny” język pojawił się także w komentarzu do tabel podsumowujących wyniki frekwentowności, w którym odnotowano przegrupowanie na niekorzyść produkcji polskiej i radzieckiej w porównaniu z rokiem $1954^{65}$ (to dodatkowy argument potwierdzający sensowność wyróżnienia podokresu lat 1955-1956).

Retorycznej ,zasłony dymnej” nie musieli stosować uczestnicy przywołanej już narady ekonomicznej pracowników kinematografii z 1956 r. Przedstawiciel CUK Konstanty Gordon chełpił się korzystnymi statystykami: Jeżeli chodzi o ilość tytułów, to w roku 1953 zaimportowaliśmy 56 tytułów, a w roku obecnym ilość ta prawie dwukrotnie wzrosła i zakupiliśmy 125 filmów. Jak wygląda import z punktu 
widzenia kierunków geograficznych? O ile w roku 1953 ze Związku Radzieckiego i krajów demokracji ludowej zaimportowaliśmy 48 tytutów $i 8$ tytułów z innych krajów, o tyle w roku 1956 zaimportowaliśmy 56 filmów ze Związku Radzieckiego i krajów demokracji ludowych oraz 69 filmów z krajów kapitalistycznych. Z tego krótkiego zestawienia widać, że w ciagu dwóch lat nastapit prawie dwukrotny wzrost importu filmów fabularnych oraz 8-krotny wzrost filmów zaimportowanych z państw kapitalistycznych; filmy tych ostatnich państw okazaty się najbardziej rentowne. Bardzo charakterystyczne dla importu jest rozszerzenie się wachlarza geograficznego państw, z których filmy importujemy. O ile w roku 1953 importowaliśmy filmy z 6 państw kapitalistycznych, to obecnie importujemy filmy z 15 państw kapitalistycznych. Jak widać, w okresie odwilży politycznej rękojmią pozostania na stanowisku stało się podkreślanie wzrostu danych dotyczących filmów z państw kapitalistycznych, zwłaszcza gdy można było korzystnie zestawić je z praktyką innych krajów demokracji ludowej (Dla porównania chciatbym podać pewne cyfry z innych krajów demokracji ludowej. I tak w Zwiazku Radzieckim zaimportowano 46 filmów z krajów kapitalistycznych na ogólna ilość zaimportowanych filmów 86, $w$ Czechosłowacji zaimportowano z krajów kapitalistycznych 34 filmy, w Rumunii -32 filmy $^{66}$ ).

\section{Monitorowanie widowni}

Urzędnicy resortu Albrechta byli świadomi tego, że aspekt polityczno-programowy wywotuje sprzeczności między dystrybutorem a gospodarzem sali kinowej. A to dlatego, że dojrzałość ideologiczno-artystyczna filmu i jego atrakcyjność (frekwentowność) sa pojęciami zgoła nie pokrywajacymi się ze soba w naszych warunkach politycznych i przy dotychczasowym stopniu uświadomienia znacznej czesść publiczności kinowej. I tak dla przykładu stwierdzić można, że szczytowe, z ideowo-artystycznego punktu widzenia, osiagnięcia kinematografii radzieckiej, jak ,, Wielki obywatel”, ,Lenin w październiku”, ,, Człowiek z karabinem” osiagały bardzo nieznaczne wyniki w ilościach widzów, w porównaniu z wieloma mało, względnie bezwartościowymi filmami, jak produkcji węgierskiej „Płomienie”, czeskiej „Pan Habetin odchodzi” czy zachodniej, jak austriacki film „,Zagubione melodie”. (...) Rzecz prosta, we wszystkich tego rodzaju wypadkach gospodarz sali kinowej, czy też rzecznik interesów kina (w naszych warunkach przedsiębiorstwo Okręgowy Zarząd Kina), na którego spada cały ciężar intensywnego organizowania widowni, dąży do ograniczenia wyświetlań produkcji zagrażającej wykonaniu planów ${ }^{67}$. Innymi słowy, to nie wymiar ekonomiczny, lecz polityczny (na przykład: zaangażowanie kin w bieżące akcje propagandowe) był zasadniczym budulcem planu oraz kryterium jego wykonania.

Kierownicy kin mieli także monitorować reakcje publiczności, przy czym wskazano wprost, o jakich dokładnie zachowaniach należy raportować: Dyrekcja Programowa będzie uważać w przyszłości, że tym najdalej wysuniętym nerwem, czołówka to jest wtaśnie aparat CWF $i$ wydaje mi się, że Towarzysze powinni zrozumieć, że jest rzecza zupetnie nienormalna, ale szkodliwa dla nas, że sygnaty tego typu, że powiedzmy sobie jakiś film amerykański został wygwizdany, objaw niestychanie pocieszajacy, który powinno się odpowiednio wykorzystać i politycznie wygrać i tego rodzaju wiadomości dochodza droga niezupetnie normalna. My powinniśmy zawia- 
domić Główny Urząd Kontroli Prasy i Widowisk o takiej właśnie, a nie innej reakcji publiczności, powinniśmy mieć dostateczna ilość materiału, żeby wobec takiego faktu rozpocząc kampanię prasowa. Muszę stwierdzić, ̇̇e do tej pory w aktach Dyrekcji Programowej nie posiadamy ani jednego raportu o takim fakcie ${ }^{68}$.

Monitorowanie widowni było prowadzone na wielu poziomach i przez różne instytucje. Wiadomo, że informacje od kierowników kin były przekazywane do odpowiednich komórek lokalnych komitetów wojewódzkich Partii. Przykładowo w styczniu 1949 r. zastępca kierownika Wydziału Propagandy, Oświaty i Kultury Komitetu Wojewódzkiego PPR w Lublinie prosił warszawską centralę o zajęcie stanowiska w sprawie amerykańskiego filmu Zielone lata (reż. Victor Saville), który na terenie Lubelszczyzny miał się cieszyć ogromnym powodzeniem wśród młodzieży szkolnej $i$ koltuństwa, choć jest co najmniej niepożadany. Wątpliwości lokalnych aparatczyków wywołała apoteoza chrześcijaństwa - cała akcja wskazuje, iż tylko dzięki ufności do Boga i silnej wiary zostaja pokonane wszelkie trudności w życiu ${ }^{69}$.

Interesującym źródłem wiedzy o potrzebach widowni były skargi i zażalenia przesyłane do Centrali Wynajmu Filmów. Zachował się spory ich zbiór, przy czym większość spraw dotyczyła jakości projekcji i kultury personelu w konkretnych kinach. W odniesieniu do kwestii związanych z repertuarem szczególnie często skarżono się na problemy związane z obiegiem kopii (irytację wywoływała sytuacja, gdy w sąsiedniej wsi lub pobliskim miasteczku pokazywano nowsze filmy), w tym zbyt liczne powtórki. Niekiedy odnotowywano niezadowolenie widzów z ogólnej oferty filmów kupowanych do rozpowszechniania - przykładowo w Sprawozdaniu z załatwiania skarg $i$ zażaleń za I kwartał 1955 roku ${ }^{70}$ wspomniano o głosach dopominajacych się wznowień filmów chaplinowskich i filmów osnutych na tle powieści Dickensa.

Z czasem w CUK powołano do życia Departament Repertuaru i Studiów pod kierunkiem Adama Kulika, wcześniej dyrektora w Ministerstwie Kultury, później profesora w Instytucie Psychologii Uniwersytetu Warszawskiego. Jego raporty łączą analizę treści z danymi ilościowymi (zestawienia frekwencji) oraz metodą jakościową (na przykład zbieranie informacji od kierowników kin). Ponadto raporty te miały na celu opisanie różnic zachodzących wedle kryterium geograficznego, przedstawianych niekiedy z nadmierną skrupulatnością (według podziału administracyjnego na województwa). Tylko sporadycznie wynikała z nich obserwacja równie intrygująca, jak ta dotycząca województw opolskiego i olsztyńskiego, czyli terenów zamieszkanych przez ludność autochtoniczna. Charakterystyczny dla niej jest na ogół pozytywny stosunek do filmów produkcji niemieckiej (poza zgrupowaniami ludności, która ma negatywny stosunek do ideologii reprezentowanej przez filmy NRD). W frekwencyjności uzyskują przewagę nad wojennymi filmy sensacyjne, przygodowe, komedie oraz tzw. filmy miłosne. Stosunkowo nieźle przyjmowane sa filmy muzyczne (lepiej niż w innych województwach). Wyjątkowe powodzenie uzyskat na tych terenach film ,Zagubione melodie” prod. austriac$k_{i e j}{ }^{71}$. Dostrzegano także konieczność dokładniejszego pomiaru, który odzwierciedlałby w strukturę województw - przykładowo próbowano wyjaśnić różnice we frekwencyjności poszczególnych tytułów w różnych kinach wspomnianych województw (słaba frekwencja na ,,Tosce” $i$,,Palomie” w kinie w Otmuchowie /teren zamieszkały przez ludność zza Bugal, choć te same filmy miaty olbrzymie powodzenie na wsiach opolskich zamieszkatych przez ludność autochtoniczna ${ }^{72}$ ). 
Obowiązek badania widowni miały też poszczególne ekspozytury Centrali Wynajmu Filmów. Z przywołanego już sprawozdania z krakowskiej ekspozytury za 1955 r. dowiadujemy się, że $w$ mieście Krakowie na atrakcyjność filmów zachodnich wplywa niewatpliwie ich wysoki poziom artystyczny, który potrafi ocenić, należycie zróżnicować inteligentne i coraz bardziej kulturalne społeczeństwo krakowskie ${ }^{73}$. Już w kolejnym zdaniu autor raportu mityguje się: Niemniej działaja tutaj i inne przyczyny. Sa nimi pozostałości dawnych nawyczek i przyzwyczajeń, tkwiace zwłaszcza w starszym i średnim wieku pokoleniu, drobnomieszczański snobizm i konserwatyzm. Cechy, których nie wyplenit jeszcze nurt życia i młodzieńczy entuzjazm Nowej Huty, a które powoduja, że tzw. „kottun” krakowski i nie-krakowski, bo nie tylko w Krakowie kołtuny dogorywaja, wybierze zawsze to, co zachodnie, bo bliższe jego duszy kamienicznika czy innego byłego posiada$c z a^{74}$. Jak widać, tuż przed odwilżą „drobnomieszczański snobizm” mógł się wydawać lepszym (bezpieczniejszym) wyjaśnieniem popularności filmów zachodnich niż przyczyny związane z samymi filmami (czyli ich „,wysoki poziom artystyczny").

Początkujący badacz historii kultury filmowej, usłyszawszy, że w archiwach zachowała się tak bogata dokumentacja instytucji sprawującej monopol w zakresie rozpowszechniania filmów, zatarłby zapewne z zadowoleniem ręce, przymierzając się do analizy danych sprzedażowych i frekwencyjnych konkretnych tytułów. Tymczasem wśród dokumentów GDFP oraz CUK nie udało się, niestety, odnaleźć takich informacji (choć z pewnością były one zbierane, o czym świadczy nie tylko przywołana wcześniej umowa z MOPEXAS, ale i zdrowy rozsądek - skoro porównywano wyniki między grupami państw, niezbędne były liczby). W dostępnych raportach dotyczących frekwencji za lata 1949-1956 również dominowało myślenie blokami geopolitycznymi. Z lektury dokumentów widać, że dane liczbowe niekorzystne z ideologicznego punktu widzenia bywały bądź „maskowane” (błędami arytmetycznymi), bądź przemilczane (nie towarzyszyło im omówienie), bądź przeinaczane (zabiegami retorycznymi odwracającymi wymowę danych). Przykładowo w raporcie krakowskiej ekspozytury CWF za 1955 r. informowano, że produkcja Krajów Demokracji Ludowych dobrze zniesła przypływ filmów z zachodu ${ }^{75}$, i podano garść liczb, choć akurat niekoniecznie potwierdzających przywołany wniosek: „,Skarby sultana”, film produkcji NRD, uzyskał ponad 74 tysięcy widzów, czeski film ,, W matni" $i$, Ekspres z Norymbergi” przekroczyly kazdy z osobna 36 tysięcy widzów. (...) Rekordzista w filmach produkcji zachodniej jest francuski film „Piękności nocy” z około 110 tysiacami widzów oraz „Jutro będzie za późno” z około 96 tysiacami widzów $i$, Urok szatana” z około 93 tysiącami ${ }^{76}$.

Z kolei autor komentarza do zestawień porównujących dane z 1953 i 1954 roku (zob. Tabela 2) dość lakonicznie zauważa, że zmiany w strukturze widzów ida $w$ nieco innych kierunkach niż w strukturze puli tytułów $i$ kopii. Następnie komentuje (w formule, która pojawia się także w analogicznych raportach za rok 1953 i 1955; mamy zatem do czynienia z rodzajem szablonu sprawozdawczego): 1) procentowy udziat na filmach produkcji polskiej jest znacznie wyższy od procentowego udziału tytułów polskich w ogólnej puli filmów, a prawie równy udziałowi kopii; 2) udziat procentowy widzów na filmach produkcji radzieckiej utrzymuje się $w$ dalszym ciagu poniżej procentowego udziału tytułów, a jest wyższy od procent udziału kopii tej produkcji; 3) udział procentowy widzów na filmach produkcji Dem. Lu- 
dowej w r. 1954 jest prawie dwukrotnie niższy od procentu udziału tytułów w ogólnej puli tytułów. To samo dotyczy kopii; 4) udział procentowy widzów na filmach produkcji , inne” jest prawie dwukrotnie wyższy od procentowego udziału tytułów w ogólnej puli tytułów. To samo dotyczy kopii ${ }^{77}$. Biorąc pod uwagę fakt, że dane w kolumnie 15., prezentującej udział widowni poszczególnych grup filmów, zostały źle wyliczone, wniosek z punktu 2. jest nieprawdziwy. Być może błąd arytmetyczny został popełniony celowo - ze względu na potrzeby „podkręcenia” sprawozdawczości, na co wskazywałby fakt, że autor raportu w jeszcze jednym miejscu podkreśla znaczny spadek udziału na filmach produkcji Dem. Lud oraz poważny wzrost na produkcji radzieckiej ${ }^{78}$. Tymczasem z liczb wynika niezbicie, że największy wzrost liczby widzów (ponad 145 procent z poprzedniego roku) nastąpił w grupie filmów z krajów zachodnich (,innych”) oraz polskich, o czym w ogóle w komentarzu nie ma mowy, zaś w przypadku filmów sowieckich wzrost był niewielki. Co więcej, w porównaniu z wcześniejszym rokiem procent widzów na filmach sowieckich w rzeczywistości się zmniejszył (zostało to „zamaskowane” błędem rachunkowym).

Wyrywkowe dane liczbowe na temat filmów „frekwentowanych” pojawiają się także w okólnikach, raportach z danego województwa, stenogramach zebrań lub wygłaszanych w ich trakcie referatach. I tak, z okólnika z października 1950 r. dowiemy się, że niektórzy pracownicy „Filmu Polskiego” w wypadkach niemożności nabycia biletów na filmy cieszace się wyjątkowa frekwencja (jak na przykład „Hamlet”) interweniuja osobiście u kierowników kin, wykorzystując często swoje stanowisko stużbowe. Powyższe postępowanie powoduje niezadowolenie publiczności czekajacej w kolejkach ${ }^{79}$. Z kolei w obszernym referacie zatytułowanym Polityka rozpowszechniania filmów, wygłoszonym w listopadzie 1952 r., dyrektor Dytko ujawnił nie bez niepokoju: filmy takie jak ,, Skandal w Clochemerle ”, , Jednodniowi milionerzy”, ,, Cywil na stadionie”, ,, Wesoła trójka”, „, Ślub z przeszkodami" cieszyly się rekordowym powodzeniem, a przecież te trzy ostatnie pozycje to filmy rzeczywiście słabe, o wyjątkowo watpliwym, nędznym humorze i jeżeli przy tym wszystkim stwierdzić można na takim „Cywilu na stadionie” salwy śmiechu, ogonki przed kasami itp., tzn. nasza publiczność i to publiczność rekrutujaca się spośród ludzi pracy pragnie się śmiać, szuka lekkiej rozrywki. Trzeba rzeczywiście pomyśleć o tym, aby po ciężkiej pracy, dużej ilości zebrań i narad publiczność znalazła naprawdę rozrywkę $w$ kinie ${ }^{80}$. Pół żartem, pół serio można powiedzieć, że tak rzeczywiście się stało - urzędnicy CUK myśleli o potrzebach widzów coraz intensywniej, podczas licznych zebrań i narad.

$$
* * *
$$

W 1955 r. Stanisław Albrecht został ambasadorem w Niemieckiej Republice Demokratycznej, zaś na stanowisku prezesa CUK zastąpił go inny sprawdzony towarzysz, Leonard Borkowicz, wcześniej pierwszy wojewoda szczeciński. Nie zdołał on zatamować odwilżowej fali niezadowolenia, która najpełniejsze ujście znalazła na wspomnianej już naradzie ekonomicznej pracowników kinematografii w grudniu 1956 r. Jej efektem była ostra w tonie uchwała o głębokich i poważnych szkodach $w$ życiu filmowym spowodowanych przez miniony okres. Znaczna część uchwały jest poświęcona zagadnieniom dotyczącym rozpowszechniania, przy 
czym jej autorzy i sygnatariusze zdawali sobie sprawę, że CUK nie jest jedyną instancją, którą można obarczyć odpowiedzialnością, gdyż był wykonawcą decyzji podejmowanych na wyższym szczeblu: $w$ sprawach takich jak administrowanie twórczościa lub ustalanie repertuaru i prowadzenie polityki zakupu filmów zagranicznych wina obciąża w przeważającej mierze pozafilmowe instancje kierownicze Partii i Rządu ${ }^{81}$.

W konkluzji sformułowano kilka postulatów, z których dwa dotyczyły bezpośrednio kwestii repertuarowych. Po pierwsze, żądano likwidacji komisji ocen zajmującej się doborem filmów zagranicznych i zastąpienia jej nowym ciałem, złożonym z kompetentnych przedstawicieli filmoznawstwa, krytyki twórczości, jak również przedstawicieli rozpowszechniania (organ taki faktycznie został wkrótce powołany - była to Filmowa Rada Repertuarowa). Po drugie zaś, domagano się zwiększenia liczby tytułów wprowadzonych do eksploatacji do ilości 200 rocznie. Realizacja tego celu zajęła kilka lat - liczbę tę (w odniesieniu do zagranicznych filmów pełnometrażowych) udało się przekroczyć w 1959 r. ${ }^{82}$

Natomiast ostatni postulat - proces rehabilitacji w kinematografii winien objać prócz osób również dzieła filmowe, niestusznie zdyskwalifikowane - został wprowadzony w życie tylko częściowo. Spośród wielu interesujących filmów zachodnich, które zostały nakręcone w pierwszym dziesięcioleciu po II wojnie światowej, lecz nie mogły wówczas zostać pokazane w Polsce, tylko niektóre trafiły na nasze ekrany. Spośród filmów, które otrzymały Oscara za najlepszy film (lub nominację do tej nagrody), były to: Amerykanin w Paryżu (An American in Paris, reż. Vincente Minnelli, 1951), W samo południe (High Noon, reż. Fred Zinnemann, 1952) oraz Rzymskie wakacje (Roman Holiday, reż. William Wyler, 1953). W kolejnych latach nadal nadrabiano zaległości, importując - z dziesięcioletnim ,poślizgiem” względem roku premiery w USA - tak znane (na Zachodzie) filmy, jak Wszystko o Ewie (All About Eve, reż. Joseph L. Mankiewicz, 1950) czy Bulwar Zachodzacego Słońca (Sunset Boulevard, reż. Billy Wilder, 1950), niekiedy zaś z opóźnieniem piętnastoletnim, jak w przypadku Urzeczonej (Spellbound, reż. Alfred Hitchcock, 1946) i Skarbu Sierra Madre (The Treasure of the Sierra Madre, reż. John Huston, 1948). Co najmniej trzy ważne filmy amerykańskie z okresu 1946-1953 nigdy nie zostały wprowadzone do polskich kin; los taki spotkał To wspaniałe życie (It's a Wonderful Life, reż. Frank Capra, 1946), Tramwaj zwany pożądaniem (A Streetcar Named Desire, reż. Elia Kazan, 1951) oraz Stąd do wieczności (From Here to Eternity, reż. Fred Zinnemann, 1953). Słowem, do obszernego katalogu strat, jakie Polska poniosła w dobie stalinizmu, można dodać także zubożenie oferty repertuarowej kin, w wyniku której widzowie zostali na blisko dekadę odcięci od globalnego obiegu znacznej liczby filmów uznawanych wówczas lub później za ważne.

KONRAD KLEJSA

Artykuł powstał w ramach realizacji projektu „Rozpowszechnianie filmów w Polsce w latach 1945-1989", finansowanego przez Narodowe Centrum Nauki (2016/22/E/HS2/00135). 
${ }^{1}$ W latach 1945-1949 instytucja ta działała pod nazwą Przedsiębiorstwo Państwowe „Film Polski”, w okresie 1950-1951 - pod nazwą Generalna Dyrekcja Filmu Polskiego. Ponieważ de facto było to jedno i to samo przedsiębiorstwo o charakterze państwowego holdingu, określenia Film Polski będę używał dla obu bytów prawnych. Począwszy od 1948 r., kiedy dyrekcja Filmu Polskiego formalnie opuściła Łódź, siedziba przedsiębiorstwa mieściła się w Warszawie przy ul. Puławskiej 61 (budynki te przejęła później Filmoteka Narodowa).

${ }^{2}$ Zob. zwłaszcza: A. Madej, Kino, władza, publiczność. Kinematografia polska w latach 1944-1949, Prasa Beskidzka, Bielsko-Biała 2002. Ta cenna monografia zawiera niewiele materiału dotyczącego zagadnień rozpowszechniania.

${ }^{3}$ Dostępne są źródła zastane, ale można się również pokusić o wytworzenie danych badawczych - przez wywiady czy historie mówione (szczególnie podatne na konfabulację i często ukierunkowane na autopromocję wspominającego). W odniesieniu do okresu stalinowskiego możliwość ich przeprowadzenia staje się dnia na dzień coraz bardziej ograniczona.

${ }^{4}$ Zasoby archiwalne GDFP i CUK zawierają materiały o różnorodnej tematyce, z przewagą zagadnień dotyczących produkcji filmowej, infrastruktury (wytwórni, fabryk kinotechnicznych oraz kin) oraz spraw personalnych (delegacje dla pracowników, sprawy mieszkaniowe). Szacuję, że dokumenty związane stricte $\mathrm{z}$ rozpowszechnianiem stanowią około 30 proc. obu zasobów (liczonych łącznie). Są wśród nich zarządzenia i okólniki (zarówno dyrektora Filmu Polskiego, jak i prezesa CUK, oraz dyrektorów instytucji podległych, przede wszystkim Centrali Wynajmu Filmów i Okręgowych Zarządów Kin), rozmaite zestawienia statystyczne, a także, prawdopodobnie najcenniejsze z poznawczego punktu widzenia, stenogramy narad i posiedzeń.

${ }^{5} \mathrm{~W}$ zasobie Archiwum Akt Nowych (AAN) jest niewiele dokumentów z działalności Podkomisji ds. Filmu. Teczki znane już historykom kina i omawiane w źródłowych (wciąż zbyt nielicznych) opracowaniach kultury filmowej PRL mieszczą się głównie w serii „XVIII Wydział Kultury" (rozpowszechniania dotyczy zwłaszcza teczka o numerze 32). W toku prac kwerendalnych udało się ustalić, że dokumenty Komisji mogą być rozproszone w innych seriach, na co wskazuje teczka „V - Sekretariat”, zawierająca stenogram z posiedzenia Komisji z 26 stycznia 1949 r. liczący 31 stron. Na pierwszej stronie zawiera on klauzulę: Wobec tego, że na poprzednim posiedzeniu postanowiono nie robić protokołu, a poprzestać na stenogramie (...) zostaje przyjęty wniosek: wrócić do dawnej metody, robić krótki protokół, czytany i zatwierdzony przez towarzyszy, którego jeden egzemplarz ma być wystany do KC (...) a niezależnie od tego robić stenogram niekontrolowany do własnego użytku Komisji (AAN, KC PZPR, sygn. V-8). To właśnie krótki (trzystronicowy) protokół jest w teczce XVIII-31.

${ }^{6}$ Albrecht - z wykształcenia inżynier architekt, tuż po wojnie szef propagandy w Biurze Odbudowy Stolicy - był szefem kinematografii formalnie od 1 stycznia 1948 r., ale obowiązki dyrektora Filmu Polskiego pełnił od połowy 1947 r., pod nieobecność Aleksandra Forda, który był zajęty realizacją Ulicy Granicznej w Pradze. Zob. A. Madej, On, „Kwartalnik Filmowy" 1994, nr 6 (oraz wywiad z Albrechtem w tym samym tomie).

${ }^{7}$ Warto w tym miejscu uczynić krótką dygresję. Otóż w informacji przesłanej do Wydziału Kultury KC PZPR we wrześniu 1949 r. (Pismo z Naczelnej Dyrekcji Filmu Polskiego do Wydziału Kultury KC PZPR z 2 września 1949 r., AAN, PZPR, sygn. 237/XVII-31, k. 176-178) dyrekcja Filmu Polskiego powiadamia: Jak stwierdziliśmy na podstawie materiałów nadsylanych przez Okręgowe Zarzady Rozpowszechniania Filmów, Towarzystwo Przyjaźni Polsko-Radzieckiej prowadzi w kilku miejscowościach kina stałe, $w$ których wyświetlane sa filmy dla szerokiej publiczności. (...) Kina te sa prowadzone przez TPPR w miejscowościach, w których czynne sa kina naszego Przedsiębiorstwa. (...) Zarówno kina TPPR, jak $i$ kina należace do jednostek wojskowych Armii Czerwonej wyświetlaja nie opracowane $w$ języku polskim i nie ocenzurowane filmy produkcji radzieckiej, włoskiej, francuskiej, angielskiej, amerykańskiej, a nawet niemieckiej. Wydaje się, że kluczowa jest tu informacja o projekcjach ,dla szerokiej publiczności”, co oznaczałoby, że mieliśmy do czynienia z alternatywnym obiegiem dystrybucyjnym. Co więcej, kina TPPR pokazywały filmy zagraniczne jeszcze przed ich dopuszczeniem do rozpowszechniania w Polsce (fakt, że wersje nieocenzurowane można było obejrzeć w kinach pod jurysdykcją sowiecką, jest nieco paradoksalny), co nie tylko było poważnym rozszczelnieniem kontroli ideologicznej nad repertuarem, ale zapewne także prowadziło do utraty wpływów z biletów. Przykładowo: film „Rzym, miasto otwarte” rozpowszechniany przez P.P. Film Polski od dnia 4.IV.1949 byt wyświetlany $w$ Watbrzychu $w$ kinie T.P.P.R. 
w miesiacu październiku 1948 roku (notatka służbowa Dyrekcji Kin Miejskich w Centralnym Zarządzie Rozpowszechniania Filmów PP Film Polski do Naczelnego Dyrektora z 20 września 1949 r., AAN, PZPR, sygn. 237-XVIII-31, k. 179).

${ }^{8}$ Uwaga: dane z Tabeli 1.: odnoszą się do tytułów, nie liczby kopii; nie uwzględniają wznowień, z wyjątkiem filmów pokazywanych w II RP; w nawiasach odnoszą się do liczby tytułów bez koprodukcji; w pozycji dotyczącej krajów demokracji ludowej nie uwzględniają filmów polskich; z wierszy „Liczba tytułów” oraz kolumny „Razem” nie zawsze sumują się do danych z wiersza „Liczba filmów” z uwagi na cztery koprodukcje między krajami kapitalistycznymi a krajami demokracji ludowej.

Dotychczas dostępne są trzy inne, zbliżone zestawienia. Za niewiarygodną (z zaniżonymi danymi liczbowymi) trzeba uznać tabelę przygotowaną przez Janusza Gazdę jako suplement do artykułu Ewy Gębickiej (E. Gębicka, Nie strzelać do Czapajewa! Jak po wojnie przyjmowano filmy radzieckie $w$ Polsce, „Kwartalnik Filmowy" 1993, nr 2, Suplement II Liczby wyświetlanych filmów w Polsce $w$ latach 1945-1958 wedtug krajów produkcji). Drugą próbę podjął Krzysztof Kucharski (w nierecenzowanej publikacji Kino polskie 1945-1959, Toruń 2008); to opracowanie nie zawiera wyjaśnienia dotyczącego zakresu zebranych danych (w odniesieniu do zagadnień kłopotliwych, takich jak filmy średniometrażowe, wznowienia i koprodukcje). Ponadto wydaje się, że autor nazbyt bezkrytycznie zawierzył informacjom czerpanym z - skądinąd cennego - wydania specjalnego „Filmowego Serwisu Prasowego" z 1969 r. (J. Wittek, W. Świeżyński, W. Wertenstein, J. Trafisz, $K i$ nematografia polska w 25-leciu PRL, Warszawa 1969), w którym pojawiają się błędy faktograficzne (np. jako rok polskiej premiery czechosłowackiego filmu Porwanie w obu opracowaniach wskazano 1950 r. - omyłkowo, ponieważ jest to film z 1952 r., na polskie ekrany wprowadzony w 1954 r.). Przed tym ostatnim błędem ustrzegł się Dariusz Szymański, autor zestawień prezentowanych na stronie www.naekranachprl.pl. Dane tam zawarte budzą nieco wątpliwości $z$ innych powodów (zob. także ostatni przypis w niniejszym artykule), natomiast przedstawione statystyki są inne niż moje, ponieważ uwzględniają zarówno filmy pełno-, jak i średniometrażowe (nie wszystkie filmy zostały przypisane do właściwej puli); nie jest też jasne, jak został rozwiązany problem koprodukcji i wznowień.
${ }^{9}$ Zob. E. Gębicka, Jeśli przyjeżḋ̇acie z kinem, to nie prowadźcie propagandy! Kina objazdowe $w$ latach 1944-1947, „Kwartalnik Filmowy" 1993, nr 4.

${ }^{10}$ Ocena taka wynika z pobieżnej analizy repertuarów kinowych Łodzi i Krakowa (obszerniejsze i bardziej precyzyjne dane są w przygotowaniu), a także z informacji opublikowanych w wewnętrznym biuletynie państwowego monopolisty: W maju 1949 roku byto na ekranach stałych i ruchomych 256 tytulów, w tym: produkcji radzieckiej - tytułów 126, czeskiej -10, polskiej-5, francuskiej-36, włoskiej4, angielskiej - 19, amerykańskiej - 46, szwedzkiej-7, szwajcarskiej-2, duńskiej-1 („Biuletyn Informacyjny Filmu Polskiego” 1949, nr 12, s. 9).

${ }^{11}$ D. Jarosz, Zwrot stalinizacyjny 1949-1950 i jego wplyw na funkcjonowanie organizacji społecznych, w: Nie tylko partia? Organizacje społeczne w Polsce Ludowej 1944-1989 - geneza, funkcjonowanie, znaczenie, red. T. Ruzikowski, IPN, Warszawa 2017.

${ }^{12}$ [płaż.], Czy będzie na co chodzić do kina? „Przegląd Kulturalny” 1954, nr 10 (80), s. 8.

13 J. Płażewski, Czytelnicy osądzaja repertuar filmowy 1953 roku, „Przegląd Kulturalny” 1954, nr 12 (82), s. 4. Kolejna krytyczna notatka Płażewskiego pochodzi z czerwca: rok bieżacy nie tylko nie przynosi radykalnego przełomu pod względem repertuaru, ale nie widać $w$ nim oznak minimalnej choćby poprawy. Czytelnicy - m.in. na naszych łamach - wotaja coraz donioślej i natarczywiej: „Więcej dobrych filmów!”, CWF obiecuje, a do kina jak nie było na co pójść, tak nie ma dalej ([płaż.], Obiecanki cacanki, a koniec żałosny, „Przegląd Kulturalny” 1954, nr 22 /92/, s. 7).

${ }^{14}$ J. Hochfeld, Oświata i kultura $w$ narodowym planie gospodarczym, „Kuźnica” 1949, nr 15 (188), s. 2.

${ }^{15}$ L. Bukowiecki, Wspomnienia kinomana, Anagram, Warszawa 1997.

${ }^{16}$ Ze wspomnień Leona Bukowieckiego wynika, że ta ,pierwsza" komisja obradowała - jeszcze w ,łódzkich” czasach „Filmu” - w ówczesnej siedzibie pisma (przy ul. Narutowicza 69). Poza Bukowieckim w jej skład wchodzili Jerzy Giżycki i Zbigniew Pitera, od czasu do czasu w pokazie brat udziat Ludwik Perski, a rzadko pokazywali się inni (L. Bukowiecki, dz. cyt., s. 142).

${ }^{17}$ Zarządzenie 51 z 18 marca 1948 r., AAN, GDFP, t. 113. Komisji przewodniczył delegat Biura Programowego, o zakupie filmów decydowano jednomyślnie, a w wypadku roz- 


\section{KONRAD KLEJSA}

bieżności opinii decyzję miał podejmować Naczelny Dyrektor.

${ }^{18}$ Regulamin Komisji Kwalifikacyjnej PP Film Polski dla ocen filmów importowanych i eksportowanych - Zarządzenie nr 127 Naczelnej Dyrekcji Filmu Polskiego z dn. 29 sierpnia 1949 r., AAN, MKiS, GDFP, t. 116.

${ }^{19}$ Passus ten brzmi: Komisja dokonuje oceny przedstawionego filmu, ustala propozycje sposobu opracowania filmu (dla rozpowszechniania $w$ kraju lub zagranica) i sktada wniosek protokólarny, biorac pod uwage wartość ideologiczna, użyteczność społeczna $i$ znaczenie propagandowe filmu. Zob. załącznik nr 5 (Regulamin Komisji Ocen Filmów do Zakupu i Sprzedaży) do Zarządzenia nr 14 Generalnego Dyrektora Filmu Polskiego z 25 lutego 1950 r., AAN, MKiS, GDFP, teczka 117, k. 133.

${ }^{20}$ Funkcję tę pełniła - zgodnie z aktami prawnymi przywołanymi w poprzednich przypisach kolejno jako dyrektor Biura Programowego, następnie Biura Zagranicznego Obrotu Filmów, wreszcie Dyrekcji Programowej do połowy 1950 r. (później objęła stanowisko dyrektora stołecznej Wytwórni Filmów Dokumentalnych).

${ }^{21}$ Radkiewicz nadzorował bezpiekę od początku 1944 r., jeszcze w rządzie PKWN-u. Po odejściu z ministerstwa w 1956 r. objął tekę Ministra ds. Państwowych Gospodarstw Rolnych.

${ }^{22}$ Nawiasem mówiąc, w strukturach GDFP i CUK pracowały na eksponowanych stanowiskach (upoważniających do uczestnictwa w zebraniach aktywu) także: Maria Sokorska (pierwsza żona Włodzimierza Sokorskiego) oraz Ewa Borejszyna (żona Jerzego Borejszy).

${ }^{23}$ Zarządzenie nr 31 z 18 czerwca 1951 r., AAN, GDFP, t. 119, k. 87-88.

${ }^{24}$ B. Węsierski, Co ujrzymy na ekranach w 1955 roku, „Przegląd Kulturalny” 1955, nr 5 (127), s. 5. Nie udało się ustalić, jacy przedstawiciele krytyki filmowej zasiadali w tym gremium w 1955 r.; przypuszczalnie byli wśród nich Bukowiecki i Płażewski. Zapewne zaliczał się do nich także Aleksander Jackiewicz, na co wskazuje następujący fragment jego felietonu z ,Nowej Kultury": Należe do tych uprzywilejowanych, którzy większość filmów oglądają niedtugo po ich przybyciu do Polski. Później filmy znikaja na rok, na dwa, na trzy. (...) Czasem dowiaduję się, że filmu nie kupiliśmy w obawie, aby nie wptynąt źle na nasza niewinność ideologiczna (A. Jackiewicz, Co się dzieje na ekranach, „Nowa Kultura”, 15 lipca 1956, s. 8).

${ }^{25}$ L. Bukowiecki, dz. cyt., s. 135.

${ }^{26}$ Tamże, s. 134.
${ }^{27}$ Tamże, s. 145.

${ }^{28}$ Tamże, s. 146. Ze wspomnień Bukowieckiego wynika, że do filmów przedstawianych Komisji dostarczano niechlujnie sporządzone listy dialogowe, niekiedy zaś filmy były tłumaczone a vista - na przykład przez samego Bukowieckiego, który - pochodząc z rodziny włościańskiej - odebrał przed wojną staranne wykształcenie. We wspomnieniach przywołuje on anegdotę o thumaczeniu a vista filmu Hamlet Laurence'a Oliviera przed audytorium, którego członkiem był Tuwim.

${ }^{29}$ S. Albrecht, Po festiwalu w Cannes, „Film” 1951, nr 19, s. 5.

${ }^{30}$ Projekt uchwały BP KC PZPR w sprawie kinematografii z grudnia 1949 r., AAN, KC PZPR, Wydział Kultury, sygn. 237/XVIII-31, k. 63. W cytatach $\mathrm{z}$ dokumentów źródłowych zachowano pisownię oryginalną.

${ }^{31}$ Protokół zebrania aktywu FP Film Polski z 28 stycznia 1950 r., AAN, MKiS, GDFP, t. 141, k. 9.

32 Tamże, k. 11.

${ }^{33}$ Tamże, k. 10.

${ }^{34}$ Protokół zebrania aktywu FP Film Polski z 28 stycznia 1950 r., AAN, MKiS, GDFP, t. 141, k. 11.

${ }^{35}$ Notatka służbowa do Dyrektora Generalnego, S. Albrechta, podpisana przez Dyrektora Biura Zagranicznego Obrotu Filmów, R. Radkiewiczową, AAN, KC PZPR, Wydział Kultury, sygn. 237-XVIII-32, k. 39.

${ }^{36}$ Notatka kierownika Wydziału Kultury, tow. Wojtyga L., do tow. Hoffmana, AAN, KC PZPR, Wydział Kultury, sygn. 237-XVIII-32, k. 45.

${ }^{37}$ Produkcja angielska - załącznik do notatki poufnej do Dyrektora Generalnego z 30 września 1950 r., AAN, KC PZPR, Wydział Kultury, sygn. 237-XVIII-32, k. 46.

${ }^{38}$ Filmy M.P.E.A - załącznik do notatki poufnej do Dyrektora z 30 września 1950 r., AAN, KC PZPR, Wydział Kultury, sygn. 237-XVIII-32, k. 48.

${ }^{39}$ Było to orędzie przedstawione w marcu $1950 \mathrm{r}$., zainicjowane przez fizyka Frédérica Joliot-Curie (zięcia Marii Skłodowskiej-Curie), wzywające do przeprowadzenia ogólnoświatowego referendum w sprawie zakazu używania broni nuklearnej. Związek Radziecki i państwa demokracji ludowych wykorzystały orędzie do walki politycznej, inicjując zbieranie podpisów pod apelem, który rzekomo miała poprzeć niemal cała dorosła populacja ZSRR i Polski.

${ }^{40}$ Produkcja francuska - załącznik do notatki poufnej do Dyrektora Generalnego z 30 września 1950 r., AAN, KC PZPR, Wydział Kultury, sygn. 237-XVIII-32, k. 49-50. 
${ }^{41}$ Produkcja angielska... dz. cyt., k. 47.

${ }^{42}$ Tamże.

${ }^{43}$ Tamże.

${ }^{44}$ Tamże.

${ }^{45}$ Filmy M.P.E.A dz. cyt., k. 48.

${ }^{46}$ Gordon poświęca tym zagadnieniom wiele miejsca. Fragment najistotniejszy dla badaczy zagadnień importu i exportu filmów w PRL brzmi: Z krajami demokracji ludowej ceny sa jednakowe za filmy importowane i eksportowane. Jeśli importujemy film z NRD i eksportujemy, to cenę placimy tę samą. Za filmy radzieckie płacimy taniej niż oni płaca nam za filmy polskie, to jest zrozumiałe z punktu widzenia ilości widzów i ilości kin. (...) Ceny te ksztattuja się dla nas dodatnio. (...) Jeżeli chodzi o ilość, to cyfry kształtuja się korzystnie, jeżeli my zakupujemy 4 filmy czeskie, to Czechostowacja zakupuje od nas 6 filmów polskich. Jeżeli my zakupujemy jeden film butgarski, to Bułgaria zakupuje 4 filmy polskie. Przyczyna tego stanu rzeczy jest duża ilość filmów odrzucanych, przeciętnie można powiedzieć, że 75\% filmów jest odrzucanych, biorac pod uwage cała produkcje. W wypadku ZSRR, skąd zaimportowaliśmy $w$ tym roku 36 filmów, a wyeksportowaliśmy 5 filmów, sytuacja jest nieco inna. Ceny za importowane filmy radzieckie sa bardzo różne, za filmy kolorowe, które $w$ tej chwili wynosza 80\% filmów zakupywanych, płacimy mniej niż za filmy innych krajów demokracji ludowej. (...) Jeszcze chciałbym zaznaczyć, że mówiąc o umowach ramowych, należy zwrócić uwage na to, że w żadnej umowie przez nas podpisanej nie ma mowy o tym, że trzeba zakupywać wszystkie filmy (Narada ekonomiczna pracowników kinematografii, AAN, MKiS, CUK, t. 60, k. 121-122).

${ }^{47}$ Narada ekonomiczna pracowników kinematografii, AAN, MKiS, CUK, t. 60, k. 121. Przyszłych badaczy zagadnień importu i eksportu w kulturze filmowej PRL zapewne zainteresuje informacja o cenach: udało nam się dośrubować ceny filmów importowanych do poziomu najniższego w krajach demokracji ludowych, doprowadziliśmy do przeciętnej ceny 2 tys. 600 dolarów za jeden film. Zestawienie tej kwoty z kwota przeciętnych zysków brutto wyniesie około 5 milionów zl., świadczy to o niezwykle poważnej rentowności (k. 122).

${ }^{48}$ Nazwisko Korngold pojawia się w protokołach zebrań GDFP i CUK kilkukrotnie, ale bez imienia. Jego ustalenie było możliwe dzięki teczce z preliminarzami budżetowymi na 1955 r., dzięki której wiemy, że Korngold miał na imię Jan, a miesięczny koszt funkcjonowania przedstawicielstwa CWF w Paryżu, za- trudniającego etatowo 3 osoby, miał wynosić w 1955 r. ponad 464 tys. franków francuskich (AAN, MKiS, CUK. t 166, k. 57). Z kolei ze znacznie wcześniejszego Regulaminu Przedstawicielstwa Centrali Wynajmu Filmów w Paryżu wynika, że obejmowało ono swoim zasięgiem Francję, Włochy, Anglię, Belgię i Holandię (AAN, MKiS, GDFP, t. 119, k. 74).

${ }^{49}$ Protokół surowy zebrania Rady Generalnej Dyrekcji Filmu Polskiego w dniu 24 marca 1950 r., AAN, MKiS, GDFP, t. 134, k. 22.

${ }^{50}$ Działalność MOPEXAS była przedmiotem analizy w odniesieniu do Czechosłowacji zob. J. Bláhová, The Good, the Bad, and the Un-American: The Czechoslovak Film Monopoly, Hollywood, and American Independent Distributors, „Post Script” 2011, nr 2, s. 9-20.

${ }^{51}$ Umowa zawarta 17 kwietnia 1947 r. między towarzystwem Motion Pictures Export Association w osobie p. Ludwika Kanturka a Przedsiębiorstwem Państwowym Film Polski w osobie dyr. J. Toeplitza, AAN, PPR, sygn. 295-XVII-9.

${ }^{52}$ Protokół zebrania Rady GD Filmu Polskiego z 24 marca 1950 r., AAN, MKiS, GDFP, sygn. 134, k. 22.

${ }^{53}$ Zob. zdigitalizowany egzemplarz programu na portalu łódzkiego Muzeum Kinematografii Kino ulotne - polskie programy filmowe: http://kat.kinomuzeum.eu/?product=dziennikmarynarza (dostęp: 23.10.2019).

${ }^{54}$ W Polsce wydano także scenariusz filmu, z przedmową młodego krytyka Krzysztofa Teodora Toeplitza: M. Wilson, Sól ziemi, tłum. I. Nomańczuk, Filmowa Agencja Wydawnicza, Warszawa 1955.

${ }^{55}$ Protokół zebrania Rady GD Filmu Polskiego z 24 marca 1950 r., AAN, MKiS, GDFP, t. 134, k. 26.

${ }^{56}$ Na przykład: Analiza działalności Okręgowego Zarządu Kin w Bydgoszczy w zakresie wykonania planu usług w 1952 r., AAN, MKiS, CUK, t. 172, k. 74. Największy pożytek z takich dokumentów jest związany z uwzględnionymi w nich danymi o liczbie miejsc w poszczególnych kinach (na ich podstawie wyliczano parametr ,liczba seansomiejsc”).

${ }^{57}$ Protokół z posiedzenia Rady Generalnej Dyrekcji Filmu Polskiego w dniu 19 listopada 1951 r., AAN, MKiS, GDFP, t.137, k. 136.

${ }^{58}$ Polityka rozpowszechniania filmów - referat wygłoszony przez Ob. Dyr. Dytko na posiedzeniu Kolegium CUK w dniu 20 listopada 1952 r., AAN, MKiS, CUK, t. 6, k. 118.

${ }^{59}$ Okólnik nr 32. Instrukcja o repertuarowaniu i sprawozdawczości programowej z 19 maja 1951 r., AAN, MKiS, GDFP, t. 152, k. 77. 


\section{KONRAD KLEJSA}

${ }^{60}$ Polityka rozpowszechniania filmów... źr. cyt., k. 119.

${ }^{61}$ Uwagi do sprawozdania z wykonania planu pracy CUK za drugi kwartał 1954 r., AAN, MKiS, CUK, t. 40, k. 17.

${ }^{62}$ Sprawozdanie z wykonania planu pracy CUK za drugi kwartał 1954 r., AAN, MKiS, CUK, t. 50, k. 50 .

${ }^{63}$ Wykonanie planu gospodarczego kinematografii za rok 1954, AAN, MKiS, CUK-2, t. 13, k. 9.

${ }^{64}$ Rozpowszechnianie filmów przez Ekspozyturę Centrali Wynajmu Filmów w Krakowie w roku 1955, AAN, MKiS, CUK, t. 15, k. 69.

${ }^{65}$ Tamże, k. 68. Według tych danych w 1954 r. na produkcje polskie sprzedano 17 proc. biletów, a w 1955 - 11 proc.; produkcje radzieckie miały 43 proc. widowni w 1954 r., a 36 proc. w roku kolejnym, zaś filmy z krajów demokracji ludowych - 18 proc. w 1954 i 20 proc. w 1955 r. Największy wzrost odnotowały filmy ,innych kinematografii” - z 21,5 do 32,5 proc. widowni.

${ }^{66}$ Narada ekonomiczna pracowników kinematografii, AAN, MKiS, CUK, t. 68, k. 121.

${ }^{67}$ Uwagi dotyczące organizacji odcinka rozpowszechniania filmów (1954 r.). AAN, MKiS, CUK, t. 3, k. 44.

${ }^{68}$ Konferencja z 28 stycznia 1950 r., AAN, MKiS, GDFP, t. 141, k. 81-82.

${ }^{69}$ Pismo Wydziału Propagandy, Oświaty i Kultury Komitetu Wojewódzkiego PPR w Lublinie do Wydziału Propagandy, Kultury i Sztuki Komitetu Centralnego PZPR w Warszawie z 29 stycznia 1949 r. AAN, PPR, sygn. 237/XVIII-31, k. 150.

${ }^{70}$ Sprawozdanie załatwienia skarg i zażaleń w Centrali Wynajmu Filmów i Ekspozyturach CWF za I kwartał 1955 r., niepodpisany do- kument z 6 kwietnia 1955 r., AAN, MKiS, CUK, t. 79, k. 96.

${ }^{71}$ Analiza wyników frekwencji na filmach fabularnych na wsi za okres I-V 1954 r. z 13 XII 1954 r., podpisana przez dyr. Departamentu, Adama Kulika, AAN, MKiS, CUK, t. 58, k. 8.

${ }^{72}$ Tamże, k. 9.

${ }^{73}$ Rozpowszechnianie filmów przez Ekspozyturę Centrali Wynajmu Filmów w Krakowie w roku 1955, AAN, MKiS, CUK, t. 15, k. 68.

74 Tamże, k. 69.

75 Tamże, k. 67.

${ }^{76}$ Tamże.

${ }^{77}$ Wykonanie planu gospodarczego kinematografii za rok 1954, AAN, MKiS, CUK-2, t. 13, k. 18.

${ }^{78}$ Tamże, k. 11.

${ }^{79}$ Okólnik nr 8 z dnia 31 października 1950 r., AAN, MKiS, GDFP, t. 121, k. 102.

${ }^{80}$ Polityka rozpowszechniania filmów... źr. cyt., k. 120.

${ }^{81}$ Uchwała podjęta przez Uczestników Krajowej Narady Ekonomicznej Pracowników Kinematografii obradującej w dniach 3, 4 i 5 grudnia 1956 r., AAN, MKiS, CUK, t. 69, k. 30.

${ }^{82}$ Wskazanie 1959 r. byłoby zgodne z obliczeniami Kucharskiego (Kino polskie... dz. cyt., s. 137) oraz Szymańskiego (http://naekranachprl.pl/wp-content/uploads/20 18/11/210.pdf /dostęp: 23.10.2019/), przy czym o konieczności weryfikacji danych i statystyk z tej ostatniej bazy w odniesieniu do poszczególnych krajów świadczy choćby fakt, że tabela filmów wprowadzonych na ekrany w roku 1959 opisuje Okno na podwórze jako film sowiecki, a Iwana Groźnego - spisek bojarów jako film francuski (http://naekranachprl.pl/wp-content/uploads/2018/11/41.pdf /dostęp: 23.10.2019). 